\title{
Deer, wolves, and people: costs, benefits and challenges of living together
}

\author{
Jean-Louis Martin ${ }^{1, *}$, Simon Chamaillé-Jammes ${ }^{1}$ and Donald M. Waller ${ }^{2}$ \\ ${ }^{1}$ Centre d'Écologie Fonctionnelle et Évolutive UMR 5175, CNRS, Université de Montpellier, \\ Université Paul Valéry Montpellier, EPHE - PSL, IRD, 34293 Montpellier Cedex 5, France \\ ${ }^{2}$ Department of Botany, University of Wisconsin-Madison, Madison, WI 53706, USA
}

Running head: Deer, wolves and people

*Author for correspondence (E-mail: jean-louis.martin@ cefe.cnrs.fr; Tel.: +33 467613 264).

\begin{abstract}
Human-driven species annihilations loom as a major crisis. However the recovery of deer and wolf populations in many parts of the northern hemisphere has resulted in conflicts and controversies rather than in relief. Both species interact in complex ways with their environment, each other, and humans. We review these interactions in the context of the ecological and human costs and benefits associated with these species. We integrate scattered information to widen our perspective on the nature and perception of these costs and benefits and how they link to each other and ongoing controversies regarding how we manage deer and wolf populations. After revisiting the ecological roles deer and wolves play in contemporary ecosystems, we explore how they interact, directly and indirectly, with human groups including farmers, foresters, shepherds, and hunters. Interactions with deer and wolves generate various axes of tension, posing both ecological and sociological challenges. Resolving these tensions and conflicts requires that we address key questions using integrative approaches: what are the ecological consequences of deer and wolf recovery? How do they influence each other? What are the social and socio-ecological consequences of large deer populations and wolf presence? Finally, what key obstacles must be overcome to allow deer, wolves and people to coexist? Reviewing contemporary ecological and
\end{abstract}


sociological results suggests insights and ways to improve our understanding and resolve longstanding challenges to coexistence. We should begin by agreeing to enhance aggregate benefits while minimizing the collective costs we incur by interacting with deer and wolves. We should also view these species, and ourselves, as parts of integrated ecosystems subject to long-term dynamics. If co-existence is our goal, we need deer and wolves to persevere in ways that are compatible with human interests. Our human interests, however, should be inclusive and fairly value all the costs and benefits deer and wolves entail including their intrinsic value. Shifts in human attitudes and cultural learning that are already occurring will reshape our ecological interactions with deer and wolves.

Key words: herbivores, carnivores, ecological cascades, human-wildlife conflict, livestock, human health.

\section{CONTENTS}

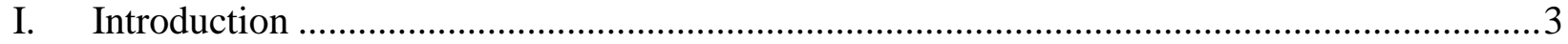

(1) Deer and wolves, the consequences of a shared history ......................................... 4

(2) Wolves and humans, a complex relationship ........................................................ 5

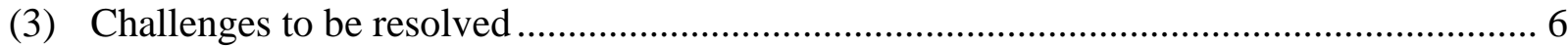

II. Deer and wolves, from decline to recovery: how and why did it happen?........................6

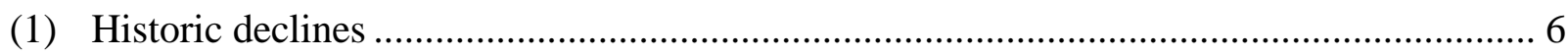

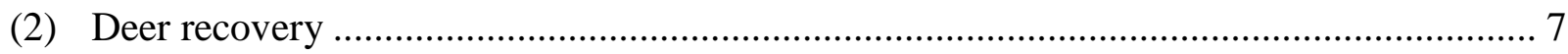

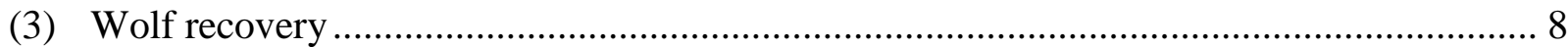

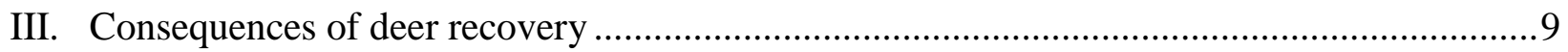

(1) Positive and negative perceptions: an assessment in progress ..................................... 9

(2) Direct and indirect effects on forest ecology ....................................................... 10

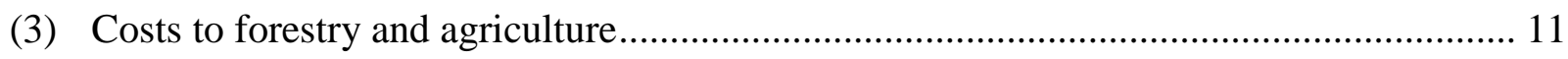

(4) Costs to human safety and to human and wildlife health ....................................... 11

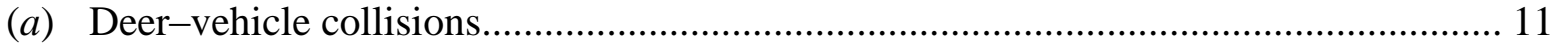

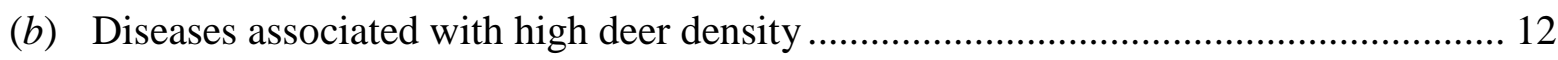

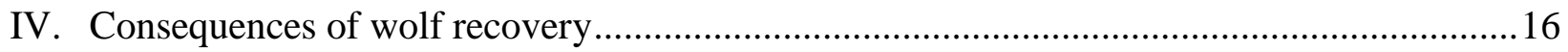

(1) Wolves and biodiversity: hypotheses, facts, and reasons for an ongoing debate ............ 16 


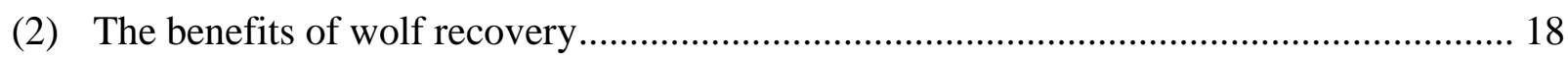

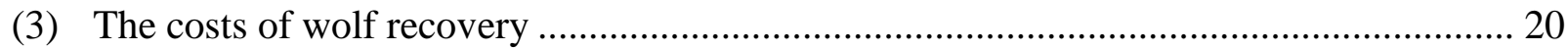

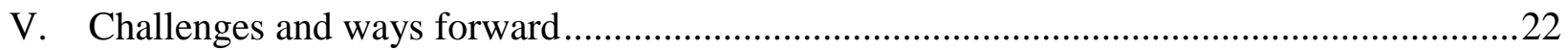

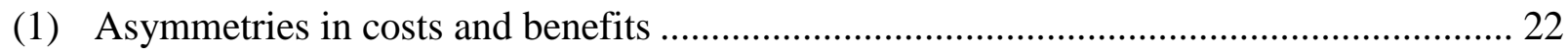

(2) Acceptance versus conflict, a matter of time, place and species ................................. 24

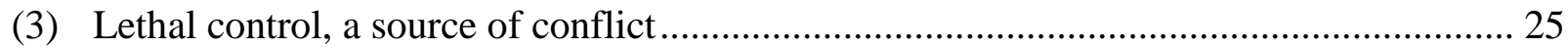

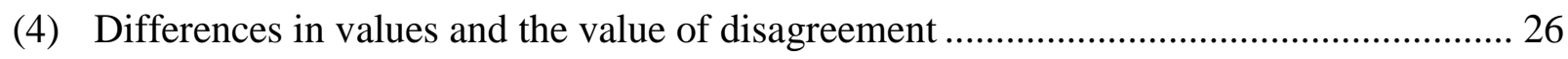

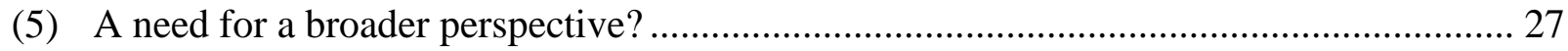

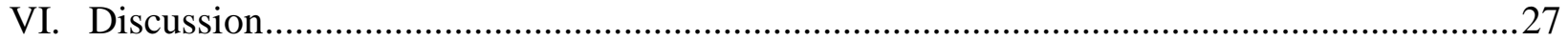

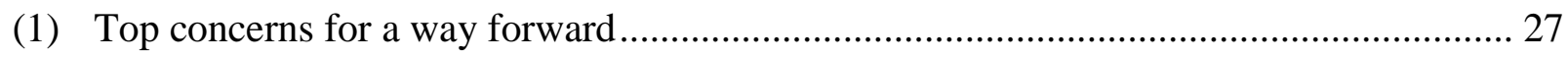

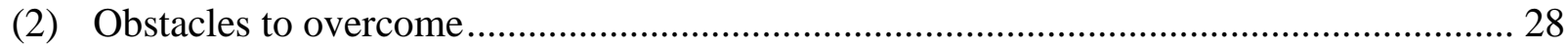

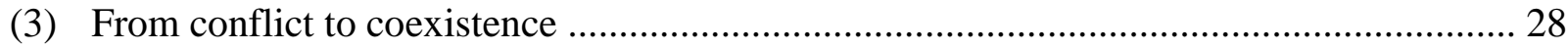

VII. Conclusions

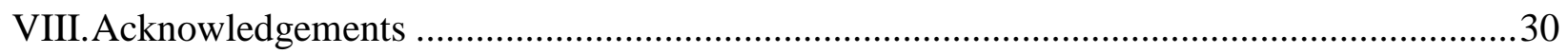

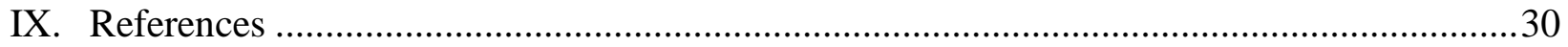

\section{INTRODUCTION}

Fear of a major human-driven species annihilation looms as a major crisis (Ceballos, Ehrlich, \& Dirzo, 2017). However, the restoration of deer (cervid ungulates) to abundant population levels in the northern hemisphere, and the recolonization of lost ground by wolves (Canis lupus), their main predators, have not resulted in relief but in conflicts and controversies around their interactions with their environment, each other, and humans. These conflicts challenge us to think hard about what we value in wildlife [for deer: e.g. Nelson (1998) and Moss (1999); for wolves: Nie (2002) and Hermann, Voß \& Menzel (2013)]. Here, we review the ecological and sociological costs and benefits that have been identified as accompanying the recovery of these species, in a synthetic effort to understand the underlying reasons for conflicts and controversies and to highlight questions to be addressed to help resolve the challenges we face when deer, wolves and people and their livestock live together. 


\section{(1) Deer and wolves, the consequences of a shared history}

We label deer 'herbivores' because they are highly adapted to find, ingest, and digest a range of woody browse and herbaceous species. But viewing deer only as plant consumers ignores millennia of additional selective forces that have moulded them. Historically, deer have shared habitats with wolves, cougar (Puma concolor), and other predators. Perceiving deer only as plant eaters seeking to maximize food intake neglects this shared history and its impact on deer bodies and behaviour (Byers, 1997; Geist, 1998). From studies in places where wolves persisted, we know their importance in deer population dynamics through the moulding of their life-history and population growth characteristics (Messier, 1994; Peterson et al., 2014). We can also infer the strength of these effects from the fact that 'bottom-up' effects of ecosystem productivity on deer populations are strongly damped in the presence of wolves (Crête, 1999; Ripple \& Beschta, 2012; Letnic \& Ripple, 2017). These behavioural adjustments of deer trading off foraging for safety in the presence of wolves (Creel \& Christianson, 2008; Chamaillé-Jammes et al., 2014) lead to nutritional costs and reduced impacts on vegetation (Letnic \& Ripple, 2017). This may be perceived erroneously as the result of a bottom-up control of the ungulate populations (Christianson \& Creel, 2010; Martin et al., 2010).

When predators are present, spatial heterogeneity in predation risk can create a "landscape of fear" (Laundré, Hernández \& Ripple, 2010) that affects the distribution and movement of deer, how they forage, and thus the distribution of herbivore-sensitive plants across the landscape with cascading effects on other species. In the absence of predators, deer are more homogeneously distributed resulting in more intensive and widely distributed impacts as well as ecological homogenization (Rooney et al., 2004). Although the historical proposition that predators reduce plant consumption by herbivores (Leopold, Sowls \& Spencer, 1947; Hairston, Smith \& Slobotkin, 1960; Flader, 1974) has been challenged (e.g. Caughley, 1970, 1983; Colinvaux, 1979), recent research substantiated the idea that natural landscapes that have lost carnivores undergo substantial ecological changes (Terborgh \& Estes, 2010; Ripple et al., 2014; Atkins et al., 2019). The differences between natural landscapes with or without carnivores may be perceived as positive or negative depending on the particular impact and on the perspective of different human stakeholders. 


\section{(2) Wolves and humans, a complex relationship}

The relationship between wolves and humans has a long and complex history (Moriceau, 2011; Alleau \& Linnell, 2015; Linnell \& Alleau, 2016; Treves \& Bonacic, 2016; Lescureux, 2018). In many societies, observations of, and interactions with, wolves led to cultural learning in humans [Lescureux \& Linnell (2010, 2013) and references therein], potentially leading to respect (Boitani, 1995; Treves \& Bonacic, 2016). Humans also often recognized that, like us, wolves cooperate in hunting and care for their kin (Drompp, 2011). Human attitudes towards wolves also were shaped by the multifaceted interactions among geography, history, beliefs and culture, including the local history of interaction between wolves and people [Boitani (1995), Mech \& Boitani (2003), Lescureux \& Linnell (2010, 2013), Moriceau (2011) and references therein]. Hunters, nomadic or sedentary shepherds, farmers, and urbanites have all developed idiosyncratic, and sometimes deeply contrasting, attitudes towards wolves; attitudes that shifted with context, place and time [Lescureux \& Linnell (2013); shifting baseline sensu Pauly (1995)]. In most human societies sharing wolves' original range, wolves occupied a special place. They were associated with the warrior class among Indo-Germans (McCone, 1987) and Inner Asians (Drompp, 2011). In Roman mythology, a She-wolf nursed and saved Mars' twin sons. In the Caucasus wolves were seen as a symbol of strength, independence and freedom (Layton, 2014). This contrasted with their perception as evil and cruel by the Zoroastrian pastoralists (Drompp, 2011) who nevertheless showed great reverence for its domesticated kin, the dog (Foltz, 2010). In western cultures, strong attitudes against wolves have been, and still are, prevalent. The status of wolves often contrasts markedly with the status of most other large mammals, and especially with attitudes towards domesticated wolves (Treves \& Bonacic, 2016). Indeed, thousands of years ago, the special human-wolf relationship brought wolves into the human family as dogs, for good and bad (Treves \& Bonacic, 2016). Since this distant past, the advent of livestock herding motivated the eradication of wolves from many landscapes they once shared with us (see Lescureux, 2018).

Today, wolves are still among the few animals for which National Parks do not necessarily provide a safe haven from legal hunting or culling, even in Europe and North America where they are legally protected (Haber, 1996). In parts of the U.S.A., for example, hunting for wolves can occur over extended hunting seasons, with little bag limit, and no restriction on killing animals with dependent young. Although such practices are widely accepted for many species 
considered as pests (e.g. corvids, rats, invasive non-natives, etc.), they breach accepted hunting ethics and regulations set for most wild animals (Haber, 1996).

\section{(3) Challenges to be resolved}

Across much of Western Europe and North America, cervid ungulates became far more abundant during the 20th and early 21 st centuries. In response, wolves, where protected, are making a comeback too. But resurging populations of deer and wolves are coming into increased conflict with people, especially farmers, foresters, shepherds or hunters. They also generate conflict among segments of increasingly urbanized human societies. We review the ecological and sociological challenges these shifts in distribution and abundance pose, in particular: (1) how and why deer and wolves have shifted in distribution and abundance historically; (2) the ecological consequences of deer and wolf recovery; (3) the social and socio-economic consequences of large deer populations and of wolf recovery and, finally, (4) the questions to be addressed to overcome the challenges posed by deer, wolves and people living together.

\section{DEER AND WOLVES, FROM DECLINE TO RECOVERY: HOW AND WHY DID IT HAPPEN?}

\section{(1) Historic declines}

Between 1450 and 1900, white-tailed deer (Odocoileus virginianus) and mule deer (O. hemionus) populations in what became the U.S.A. declined from an estimated 40+ million individuals to fewer than half a million in 1900 [see McCabe \& McCabe (1984), Webb (2016) and references therein]. This largely reflected unregulated commercial and subsistence hunting fuelled by a growing number of settlers. By the early 20th century deer populations were extirpated, or on the brink of extinction, in many eastern states. In Europe, large ungulate populations including deer had become similarly rare or extirpated in many areas by the 19th century (Boitani, 1995). In year 1500 an estimated 400000 wolves (Hampton, 1997) probably coexisted with an abundant human population (Mann, 2005) in what became the U.S.A. That number suggests that their prey must have been similarly abundant until European colonists transformed the continent (see 
McCabe \& McCabe, 1984). In Europe, wolves remained widespread and locally abundant until the 18 th century.

In the U.S.A., wolves declined to become extinct in 47 of the lower 48 states by the mid 20th century, remaining only in northern Minnesota. In Europe they were exterminated from most parts by the first half of the 20th century (Delibes, 1990, Hindrikson et al. 2017). Paradoxically, wolves were extirpated earlier in the sparsely settled Nordic countries, yet retained viable populations in many Mediterranean parts of Europe despite a long history of dense human populations (e.g. see Boitani \& Linnell, 2015). Thus, habitat loss, scarcity of their natural prey, and human hunting, often organized at the state level, have all contributed to these declines (Treves et al. 2017 and references therein)

\section{(2) Deer recovery}

Today, a mere century later, over 30 million white-tailed deer alone inhabit North America (VerCauteren, 2003). The 20th century also witnessed similar increases in deer abundance and distribution across Europe, (Fuller \& Gill, 2001). Over 10 million roe deer (Capreolus capreolus) inhabit western Europe, not counting other ungulates which have also increased (Burbaité \& Csanyi, 2009). In Scotland, the red deer (Cervus elaphus) population has increased to over 300,000 individuals (Clutton-Brock, Coulson \& Milner, 2004). The current standing biomass of large ungulates in Europe is estimated at 0.75 billion $\mathrm{kg}$, representing a consumption of approximately 20 million tons/year of green vegetation (Apollonio, Andersen \& Putman, 2010). We are uncertain about the degree to which bottom-up versus top-down trophic interactions contributed to these dramatic increases in deer populations. The extirpation of most deer predators certainly alleviated direct pressure on deer populations and altered deer behaviour (see sections IV.1. and IV.2.). At the same time, however, major changes in habitat and human land use occurred [e.g. see Fuller \& Gill (2001), Côté et al. (2004), Milner et al. (2006) and references therein]. Active forest management created abundant early successional habitat, edges and fragments which together boosted deer abundance. Changes in agricultural land use, including increased plantings of winter crops and reversion of abandoned fields to forest, supported higher deer densities. Milder winters and developing suburban areas interconnecting un-hunted green spaces also contributed, as has winter feeding of deer (Putman \& Staines, 2004). 
The result of these changes, together with favourable legal dispositions (e.g. the 1963 law on hunting plans in France, the 1979 Bern Convention and the 1992 Habitats Directive for Europe or the 1937 Pittman-Robertson Act in the USA), has been spectacular, continent-scale, recoveries of deer populations [for a UK historical perspective on legal status and trends in deer populations see Phillip et al. (2009)]. These count as significant wildlife conservation success stories. Ironically, we now see an excess of success as deer have become 'overabundant' across much of their range (Augustine \& DeCalesta, 2003). Their abundance has become a challenge to wildlife managers in large parts of North America and Europe (Warren, 1997) and legislation designed to protect deer may today conflict with the recognized need to manage their populations (Phillip et al., 2009). It has also led ecologists to investigate the downstream effects of such recoveries on landscapes and ecosystem functions (e.g. Waller \& Alverson, 1997; Fuller \& Gill, 2001; Rooney, 2001; Boulanger et al., 2015).

\section{(3) Wolf recovery}

The late 20th century saw the restoration and expansion of several large carnivores (Boitani, 1995; Enserink \& Vogel, 2006; Chapron et al., 2014). Across Western Europe, we now tally $12,000+$ wolves, distributed in 10 populations, spanning 28+ countries - a major conservation success (Hindrikson et al., 2017). This reflects increased prey abundance (the recovery of wild ungulates) and effective protection in the form of Europe's 1979 Bern Convention. This recovery took place despite significant increases in Europe's human population with intensified land use in many regions coupled with large areas where agricultural lands were abandoned. As for their decline, wolves' recovery has been most successful in rural areas of southern Europe but slower or non-existent in more natural, less roaded, areas of northern Europe (Chapron et al., 2014). As for deer, it resulted from a combination of changes in legal status, hunting regulations, and attitudes (Bern Convention in 1979, Habitats Directive in 1992) (Boitani \& Linnell, 2015). In the U.S.A., wolf population recoveries occurred across the western and midwestern U.S.A. while they were protected under the U.S.A. 1973 Endangered Species Act (Fritts, Bangs \& Gore, 1994; Mladenoff, Sickley \& Wydeven, 1999; Morell, 2008, 2013). However, wolf recovery proceeded

at a slower rate and to a lesser degree than deer recovery. In Europe and the U.S.A. it was slowed by legal and illegal hunting and, in places, by major roads and other human disturbances [for the 
upper midwestern U.S.A. see Thiel (1985), Mech et al. (1988) and Mladenoff et al. (1995, 1999);

for Spain see Blanco \& Cortes (2001)].

\section{CONSEQUENCES OF DEER RECOVERY}

\section{(1) Positive and negative perceptions: an assessment in progress}

How has the recovery of deer populations across North America and Europe affected people in managed or non-managed ecosystems? We can categorize perceived consequences of higher deer densities as either beneficial or detrimental (Table 1). How these are viewed often depends on context. Many celebrate the benefits that deer provide. These include opportunities to view and appreciate deer, now the commonest wild large mammal in many areas. In North America observing wildlife has become increasingly popular (Duffus \& Dearden, 1990). Deer hunters also exist in great numbers, spending considerable time and money to hunt a game species they cherish (Nelson, 1998; Sharp \& Wollscheid, 2009). Most directly, deer provide food to hunters. Venison remains popular especially among a newer clientele of hunters eager to obtain and share supplies of lean, organic meat (Cordain et al., 2002). Many hunters, however, prefer to hunt large bucks for the challenge (and trophies) this provides. Although hunting represents a sizeable industry in the U.S.A. with 11.5 million hunters spending $\$ 25.6$ billion, this segment underwent a 29\% decline between 2011 and 2016 (U.S. Department of the Interior, 2017). In the same period, wildlife-watching grew rapidly with expenditures rising $28 \%$ to $\$ 76$ billion.

While hunters and wildlife lovers welcome abundant deer for these obvious benefits, many farmers, foresters, gardeners, and public health officials have begun to focus on potentially negative effects of high deer densities (Table 1). Our knowledge of the range and extent of these effects has emerged slowly and remains incomplete. Although often obvious to specialists, many of these effects are far from evident to the general public and correspondingly neglected by those charged with managing deer populations. A complication is the differences in attitude between specialists (favourable to deer management) and the general public (less favourable) even when there is agreement on impacts being negative (Fischer et al., 2014). Finally, it is difficult to find quantitative estimates of likely cumulative ecological and economic impacts of deer and we are not aware of previous efforts to enumerate them comprehensively. 


\section{(2) Direct and indirect effects on forest ecology}

Several factors can limit deer populations including harsh winters, predation/hunting, and disease. In the hypothetical absence of these factors, deer populations are mainly controlled by the food available. When deer first colonize a forest devoid of large herbivores, the standing biomass of these resources is likely to be substantial. This biomass decreases if deer consume more than the yearly plant growth, starting with the most palatable species. This can eventually lead to a situation where deer populations remain abundant in strongly altered understories (Horsley, Stout \& DeCalesta, 2003; Côté et al., 2004; Baiser et al., 2008; Martin et al., 2010; Le Saout et al., 2014). In such situations, resources are consumed as fast as they appear but little biomass accumulates (Le Saout et al., 2014).

The impacts of abundant deer on vegetation can be dramatic. They include direct impacts on tree regeneration (Tilghman, 1989; Martin \& Baltzinger, 2002; Vila et al., 2003a,b) that act cumulatively over successive decades on multiple species to shift overall recruitment and forest composition (Bradshaw \& Waller, 2016). Deer also shift forest understories towards lesspalatable species that resist or tolerate herbivory while reducing understorey cover and diversity (e.g. Augustine \& Frelich, 1998; Rooney \& Waller, 2003; Wiegmann \& Waller, 2006; Waller, 2014). These direct impacts, in turn, trigger a cascade of indirect effects on invertebrates as diagnosed in several biomes around the world (Baines, Sage \& Baines, 1994; Suominen et al., 2003; Allombert, Stockton \& Martin, 2005b; Chips et al., 2015; Iida et al., 2016). Vertebrate communities are similarly affected, most noticeably songbirds that nest on the ground or in the understorey and, for most species, depend on invertebrates to feed their young (DeCalesta, 1994; McShea \& Rappole, 2000; Fuller, 2001; Allombert, Gaston \& Martin, 2005a; Martin, Arcese \& Scheerder, 2011; Rushing et al., 2020). The most critical evidence for these effects comes from studies where long-term/historical data are available in areas of contrasting browsing history (Martin et al., 2010). We know less about how deer affect below-ground ecosystems (Wardle et al., 2001). Nevertheless, one survey in the U.S.A. used 2-7-year-old fenced exclosures to document that deer increased soil compaction while reducing mean plant height, cover, diversity, abundance, tree growth and recruitment, and mice and tick abundance (Shelton et al., 2014). Drastic reductions in deer abundance can reverse many of these effects, although change can be slow. Partial recovery takes decades for the understorey (Balgooyen, 1995; Chollet et al., 2016), and necessarily even longer if the overstorey has been affected. After a time lag, increased cover 
in the understorey vegetation allows animal communities that depend on such cover to increase as well (Chollet et al., 2016).

\section{(2) Costs to forestry and agriculture}

Although the ecological effects of deer on forestry and agriculture have been well documented, aggregate estimates of the monetary costs of deer impacts to economic sectors like forestry and agriculture are scant. The limited information available, however, suggests that costs are significant. In the U.S.A., the cost of protecting seedlings from browsing exceeds $\$ 500 /$ ha (Schaap \& DeYoe, 1986). In Poland, the protection of seedlings/saplings against browsing summed to an estimated $€ 11-15 \mathrm{M}$ euros in $2002 / 2003$. Annual deer damage to forestry costs an estimated $€ 218 \mathrm{M}$ in Austria, $€ 3.2 \mathrm{M}$ in Finland and $€ 585,000$ in Hungary (in 2005). In Sweden, impacts of moose (Alces alces) on pine wood quality was at least $€ 50 \mathrm{M} /$ year in 2005 (Reimoser \& Putman, 2011; McWilliams et al., 2018).

In addition to their impacts on forests, deer often damage agricultural crops, damage that can be significant when their populations are high. In France (28 Mha of cropland) costs to agriculture per year were estimated at about $€ 20 \mathrm{M}$ in 2004 , against $€ 0.26 \mathrm{M}$ for Finland in 2006 (2.3 Mha of cropland), and €100-300,000/year in Slovakia (1.4 Mha of cropland) in 2001/2005 (Reimoser \& Putman, 2011), representing costs of about $€ 7 / 10$ ha for France and of $€ 1.1-1.4 / 10$ ha for Finland and Slovakia.

\section{(4) Costs to human safety and to human and wildlife health}

High deer populations can also compromise human safety and health. As for other sectors, we lack systematic compilations of these costs but the examples below illustrate how varied and substantial these can be.

\section{(a) Deer-vehicle collisions}

Every year many people are injured and some killed by hitting deer with their motor bikes, cars, trucks, or even aeroplanes. Deer-vehicle collision risks reflect traffic volume as well as deer densities interacting with local factors (Bashore, Tzilkowski \& Bellis, 1985; Finder, Roseberry \& Woolf, 1999; Langbein, Putman \& Pokorny, 2011; Hothorn, Brandl \& Müller, 2012). Across the 
whole U.S.A. there were an estimated 1.23 million deer-vehicle collisions between July 2011 and June 2012, killing about 200 people and causing more than \$4 billion in vehicle damage (State Farm Insurance 2012 http://www.insurancejournal.com/news/national/2012/10/24/267786.htm ). In Canada in 2000, 29,000 collisions occurred, 23 people died and 1887 were injured (https://www.tc.gc.ca/eng/motorvehiclesafety/tp-tp14798-1289.htm). In Pennsylvania, the U.S.A. state with the most deer-vehicle collisions, 115,000 collisions occurred in 2013 causing about $\$ 400$ million in property damage. Individual states in the U.S.A. midwest estimate 40-60,000 such accidents per year, typically injuring over 100 people, sometimes causing deaths, and incurring tens of millions of dollars in medical and property damage. In the U.K., property damage from deer collisions is about $€ 25 \mathrm{M}$ per year (Langbein et al., 2011). In Germany every year 200,000 roe deer collide with vehicles, resulting in 50 people killed and 3,000 injured. The overall cost is about $€ 490 \mathrm{M}$ (Hothorn et al., 2012). Collision costs are estimated at $€ 100 \mathrm{M} /$ year in France and $€ 163 \mathrm{M} /$ year in Finland. For Europe, overall costs to repair damaged vehicles are estimated to be over $€ 1$ billion. More unexpected, between 1990 and 2013, there were 1,088 collisions between planes and deer spp., elk (Cervus elaphus), moose, or caribou (Rangifer tarandus), with most involving deer (FAA and USDA statistics). One person was killed and 29 injured, plus appreciable property damage to the planes.

\section{(b) Diseases associated with high deer density}

Diseases associated with high deer densities are increasing in number and severity in both human and livestock populations. Human diseases borne by ticks that feed on deer include Lyme disease, babesiosis, and erhlichiosis transmitted by black-legged (Ixodes scapularis) and lone star ticks (Amblyomma americanum). In North America, Lyme disease is now the most prevalent contagious disease in the U.S.A., with 20,000-30,000 cases reported annually reflecting a probable overall incidence of 300,000 new cases each year according to the Center of Disease Control and Prevention (CDC). Chronic cases are debilitating and require protracted treatment. In Europe, more than 65,000 cases of Lyme disease are treated per year (Rizzoli et al., 2011). A recent report suggests that Lyme incidence in England may be three times higher than previously estimated (Cairns et al., 2019). Babesiosis, like malaria, attacks red blood cells and can be fatal if not treated promptly. It emerged recently and is now established in seven U.S.A. states that also show high Lyme incidence. Co-infections of Lyme and babesiosis parasites in mice increase the 
severity of Lyme symptoms in mice (Bhanot \& Parveen, 2019). In Connecticut, babesiosis increased sixfold between 2001 and 2008. In Wisconsin and New York (areas with high Lyme incidence), cases of meningoencephalitis related to the spread of deer tick virus increased from around one case per year between 1958 and 2003 to 21 and 12 cases, respectively, in 2008 and 2012. Similarly, human granulocytic anaplasmosis (HGA), related to Rocky Mountain spotted fever and typhus, is now the third most frequent vector-borne disease in North America and Europe (http://www.eurekalert.org/pub_releases/2012-11/bc-lod110612.php).

Do these alarming increases in serious tick-borne diseases reflect, or merely coincide with, rapid recent increases in deer populations? This question raises controversy with different studies coming to different and sometimes conflicting conclusions. Some consider deer populations as inherently unlikely to affect Lyme incidence because deer rarely provide competent hosts for the Borellia bacterium that causes it (Telford et al., 1988). Because deer boost tick populations, however, with a mature female laying 2000+ eggs, dense deer populations multiply the number of vectors, making tick bites more likely. Similarly, the complexity of Ixodes tick life cycles, with multiple mammalian hosts [typically chipmunks (Tamia spp.), white-footed mice (Peromyscus leucopus), and deer in eastern North America], each responding in its own way to variation in food resources, predators, and Borrelia infections, leads to complex interactions, complicating our ability to tease out causal effects (Ostfeld et al., 2006, 2018; Shelton et al., 2014). Fragmented forests can also boost the density of nymphs infected with Lyme disease (Allan, Keesing \& Ostfeld, 2003). These complexities generate variation in how deer densities affect Lyme disease prevalence across ecosystems and time (reviewed in Mysterud et al., 2016). Despite these complexities, several studies suggest that dense deer populations foster higher tick populations, increasing the risk for diseases like Lyme. Many have noted the striking geographical coincidence of high deer and tick-borne disease levels. Because these might be dismissed as correlative and misleading, however, rigorous studies that experimentally reduce deer populations are more definitive. One of these showed that experimentally reducing deer numbers substantially reduced tick abundance with nymphal burdens becoming unrelated to habitat structure once deer were removed (Adler et al., 1992). Several studies have now linked densities of ticks and/or Lyme disease incidence to the abundance of white-tailed deer (Wilson, Levine \& Spielman, 1984; Wilson, Adler \& Spielman, 1985; Wilson et al., 1988, 1990; Deblinger et al., 1993; Rizzoli et al., 2011; Telford, 2017) including at fine geographic scales 
(Rand et al., 2003). Studies that failed to find relationships between deer density and Lyme incidence tend either to be non-experimental or to involve limited reductions leaving deer above a threshold density (Jordan, Schulze \& Jahn, 2007). Such threshold effects do not allow us to conclude that deer abundance is unrelated to disease incidence given the rigorous experimental evidence now available. This includes a study in Connecticut where the incidence of Lyme disease was strongly correlated to ambient deer densities (Kilpatrick, Labonte \& Stafford, 2014). A hunt there reduced deer density to 5.1 deer $/ \mathrm{km}^{2}$, reducing tick abundance by $76 \%$, exposure risk by $70 \%$, and the number of reported cases of Lyme disease by $80 \%$. The studies reviewed suggest that the high deer densities prevalent in most of Europe and North America, even under conditions where deer are not considered competent hosts for the disease (Rizzoli et al., 2011), potentially contribute to the dramatic increases in serious human infectious diseases by increasing parasite vector densities and perhaps the frequency of co-infection. Although fragmented forests and climate change have clearly also played a role, our primary option for ameliorating the 'risk landscape' is to reduce deer density (Telford, 2017). Telford (2017) also emphasizes that arguing against deer reduction as a way to control tick-borne diseases conflates its potential efficacy with sociopolitical obstacles to reducing deer numbers.

High deer densities are also associated with disease outbreaks in deer themselves, other wildlife species, and domestic livestock (e.g. Vicente et al., 2006). The first reported outbreak of bovine tuberculosis in deer (in Michigan in the 1990s) was associated with high deer density (Schmitt et $a l ., 1997)$. Increases in supplemental feeding enhanced epidemic transmission rates (Miller et al., 2003), leading to a ban in that part of Michigan on such practices. Fallow deer (Dama dama) and red deer in SW England and Wales have also tested positive for bovine TB (The Deer Initiative, 2009).

High deer densities also negatively affect other species by propagating disease. For example, white-tailed deer sustain reservoir populations of a meningeal parasite (Parelaphostrongylus tenuis) that acts as a non-fatal heartworm in deer, but as a fatal brainworm in larger ungulates like elk, moose, and caribou. In northern Minnesota where moose populations declined precipitously since the 1990s, necropsies reveal that this parasite infected $45 \%$ of 54 moose evaluated (Wünschmann et al. 2015). Such findings support recommendations to limit deer densities in areas where managers are seeking to reestablish elk and moose (e.g., Peterson et al. 2009). 
Finally, Chronic Wasting Disease (CWD) (Escobar et al., 2019), a spongiform encephalopathy similar to 'mad cow' disease and Creutzfeldt-Jacob disease in humans, is spreading rapidly across the U.S.A. and now in parts of Europe (Benestad et al., 2016). It is caused by prions that are taken up in plants and can persist in the soil for long periods (Johnson et al., 2007). In the U.S.A. it was originally endemic to a few western states but has broken out repeatedly in areas of high deer density usually in association with game farms and/or supplemental feeding. Efforts to contain such an outbreak in Wisconsin in 2002 failed. CWD has continued to increase in incidence and spread to neighbouring counties and states despite intense initial efforts by wildlife managers to reduce local deer densities and ban hunters from baiting and feeding deer. These efforts generated a strong backlash against the agency leading to the reversal of some efforts and continuing spread of the disease (Storm et al., 2013). CWD has also spread to other states and Canadian provinces (Fig. 1). Deer with CWD also pose risks to other deer species [e.g. to wild reindeer (Rangifer tarandus) in Europe (Mysterud \& Rolandsen, 2018)] and potentially to livestock.

These results make clear that high deer populations in many regions generate high costs in terms of human, wildlife, and livestock health, property damage, agricultural and forestry losses, and a complex set of threats to ecosystem services and biological diversity. True comparisons of costs, especially those related to the loss of life, and benefits are difficult to assess in comparable terms. Nevertheless, the marginal benefits of adding more deer for possible increases in license revenues and commercial activities from hunting - an estimated \$100 billion in the US in 2001 (Henderson \& Moore, 2006) may be less than the cumulative higher costs these high densities now generate.

Despite increasing research in this domain, the full range and significance of deer impacts remain unknown and unquantified. They are certainly obscure to most citizens (and decision-makers) who may only see a few of these. This selectivity of vision is exacerbated by the fact that those with special or limited interests can be expected to emphasize those particular benefits, or costs, of most interest to them (Nickerson, 1998; Mercier \& Sperber, 2011).

The fuller accounting of deer costs and benefits presented here should not be interpreted as pointing a finger at deer. Rather, the objective is to highlight the many ramifications of a situation where little top-down control is exerted on an herbivore that evolved in a world with carnivores. This evolution resulted in deer gaining reproductive and foraging efficiencies sufficient to 
withstand the predation risks faced. To enumerate fully the costs and benefits that populations of wolves and other predators provide to humans, we must include in our reckoning how these predators act to limit deer numbers and their impacts (see Gilbert et al., 2017).

\section{CONSEQUENCES OF WOLF RECOVERY}

With abundant prey available and legal protection, wolves have expanded in range and population in many regions. Recovering wolves attract public attention for their own sake and for their impact on domestic flocks of livestock. Wolves are also animals that have been and are still able to threaten humans directly (Linnell et al., 2002; Moriceau, 2011; Linnell \& Alleau, 2016). By contrast, the public rarely considers how wolves might benefit humans and natural ecosystems by mitigating undesired ecological, agricultural, forestry, and societal (health, accidents) consequences of dense deer populations.

\section{(1) Wolves and biodiversity: hypotheses, facts, and reasons for an ongoing debate}

Restored wolf populations can provide important gains for biodiversity by limiting the density of deer or other wild ungulates (Letnic \& Ripple, 2017). Positive indirect effects of wolves on understorey vegetation have also been documented in the midwestern U.S.A. (Callan et al., 2013; Flagel, Belovsky \& Beyer, 2016). Cascading positive effects on other trophic layers can follow (DeCalesta, 1994; McShea \& Rappole, 2000; Smith, Peterson \& Houston, 2003; Ripple \& Beschta, 2012; Chollet \& Martin, 2013) but these have not yet been fully investigated and remain debated (Ford \& Goheen, 2015).

Indeed, debate continues to surround the question of whether wolf populations tend to reflect ungulate abundance or whether predation from wolves controls ungulate abundance. The latter hypothesis is gaining support (Donadio \& Buskirk, 2016; Letnic \& Ripple, 2017; Mech et al. 2018). This debate parallels the long-standing controversy over whether herbivores control the abundances of individual plant species within a community or whether the plant community controls herbivore abundance (Hairston et al., 1960; Martin et al., 2010). These questions regarding the importance of top-down versus bottom-up trophic control have puzzled ecologists since the advent of ecology (e.g. see Colinvaux, 1979).

We think there may be three main reasons why controversies persist over trophic cascades. The first concerns the fact that ecologists often prefer to focus on what they consider equilibrium 
conditions rather than transient population dynamics. Without changes in population, however, the cause(s) of such perceived equilibria are rarely clear, when they do exist. Regulated populations of deer, for example, could reflect finite resources in the form of woody browse and the forbs and grasses that deer prefer to eat in spring and summer or the presence of human control by hunting, and/or wolf predation. Without a perturbation of some kind, it is difficult to infer why stability persists.

A second reason concerns the need to distinguish just how prey and predators interact. It is easy to see how higher numbers of predators like wolves might directly reduce the number of prey like deer and that lower deer abundance, in turn, could increase plant abundance. It is uncertain however if, when, and where, wolves will recover to densities at which they can have meaningful consumptive effects on their abundant prey in landscapes that are increasingly anthropized (Kuijper et al., 2016). Consumptive effects can however be complemented, or even outweighed, by non-consumptive effects (also termed risk-effects) (Creel \& Christianson, 2008). Prey respond to predators, and in particular change how they use the landscape - the places and time they spend foraging; this is the "landscape of fear" idea of Laundré et al. (2010). This affects where deer spend their time, which plants they eat, how thoroughly they exploit one patch before moving on to another (Christianson \& Creel, 2008; Chamaillé-Jammes et al., 2014), and ultimately their nutritional status (Christianson \& Creel, 2010). We can thus envision situations where the presence of wolves protects many plant populations by limiting local and/or total rates of herbivory or by reducing how selectively deer forage. These risk effects, importantly, may depend less on predator densities than on predator presence, and act even when predators remain too scarce to limit prey numbers directly (Schmitz, Beckerman \& O’Brien, 1997; Creel et al., 2008).

A third reason for controversy is that plants may increase the amount of chemical defences in their leaves or stems in response to herbivory or the presence of chemical signals associated with herbivory in nearby plants (Tallamy \& Raupp, 1991; Karban \& Baldwin, 1997). Such induced defences thus reflect a response to the local presence of an herbivore that may or may not translate to a numerical limitation on its abundance depending on the local availability of alternative food sources.

Ford \& Goheen (2015) proposed a "gold standard" for accepting when a trophic cascade is acting. This standard requires that one simultaneously shows that wolves constrain or reduce the 
abundance of deer, that deer constrain or control the abundance of the plants they eat, and that more abundant wolves favour more abundant populations of the plants deer eat. Having to show all three of these effects at the same time sets a high bar for demonstrating a trophic cascade, however, as it will prove difficult to demonstrate the action of all these forces simultaneously. This might still provide a reasonable standard if all three processes are always evident whenever trophic cascades occur. More realistically, however, one or more of these numerical responses could be hidden or difficult to demonstrate due to non-linear and transient dynamics in the system. For example, the impacts that deer are having on many plant populations, or on the understorey as a whole, may be hard to detect for years as deer populations gradually increase, reducing the density and relative abundance of certain species progressively, until a tipping point occurs when herbivory by deer suddenly greatly reduces or eliminates local populations of favoured species (lower curve, Fig. 2). Augustine \& Frelich (1998) observed such effects in Laportea. Only at this

point (B) can we easily observe how sensitive the plant's population is to deer herbivory. Beyond this point, deer impacts would again disappear as these plant species become too scarce to detect deer effects, as noted for palatable tree saplings by Bradshaw \& Waller (2016). Deer adjust by shifting to lower quality forage. Recovery of the plant population (upper curve, Fig. 2) rarely retraces the initial trajectory both because depleted plant populations provide few seed sources and because selective foraging by deer targets scarce palatable seedlings, impeding recovery. This again narrows our ability to detect deer impacts to a small part of parameter space. Trophic cascades commonly exhibit such ecological hysteresis (Wilson \& Agnew, 1992; Augustine, Frelich \& Jordan, 1998; Terborgh et al., 2010). Thus, even though all three elements in the cascade could be acting and important, it may prove difficult or impossible to demonstrate all these interactions at once. This greatly constrains our ability to meet Ford \& Goheen's (2015) rigorous criteria. This is especially true when we lack observations spanning longer time scales and wider ranges of deer-wolf-plant densities.

\section{(2) The benefits of wolf recovery}

Given that dense deer populations threaten the diversity and regeneration of forests, agricultural outputs, and human and wildlife health, we predict that restoring wolf populations would reduce these impacts. That is, if wolves limit deer numbers and impacts, their presence could have high economic value. Lacking integrated economic assessments of deer impacts, we also lack reliable 
estimates of these potential benefits. The Yellowstone studies suggested that wolves acted indirectly to modify deer behaviour, reducing their impacts on vegetation (Ripple et al., 2001; Laundré, Hernández \& Altendorf, 2001; Fortin et al., 2005). These results were challenged (Kauffman, Brodie \& Jules, 2010; Winnie, 2012; Middleton et al., 2013) to conclude that the Yellowstone data have been over-interpreted. However, recent studies in the upper midwest, of the U.S.A. documented convincingly, and in their own right, that wolf presence enhances the magnitude and spatial extent of tree regeneration (Flagel et al., 2016) and plant diversity in forest understories (Callan et al., 2013). These studies suggest that year-round stalking and hunting by wolves acts both to reduce deer populations (a numerical effect) and to modify the spatial distribution of deer browsing impacts. Their interpretation was that deer that are wary, clumped, and moving frequently might be browsing less exhaustively on palatable species, reducing impacts on these plant populations. These effects likely also depend on the history and characteristics of local wolf populations (Linnell, Swenson \& Anderson, 2001) and on how humans modify the landscapes in which these interactions occur (Melis et al., 2009; Kuijper et al., 2013, 2016; Boitani \& Linnell, 2015).

Positive effects of wolf recovery to local economies have also been investigated. In the Greater Yellowstone area, the presence of wolves increased park visitation by about $4 \%$, adding $\$ 35$ million to the local economy (Duffield, Neher \& Patterson, 2006). Yellowstone, of course, is already a famous national park with many other attractions. Non-park regions that lack clear sight lines and ample wolf viewing opportunities are less likely to benefit to the same degree, especially if the local attractiveness of wolves for tourists declines as wolves become more common. Nevertheless, protecting carnivore habitat has been positively linked to the economic development in several communities (Rasker \& Hackman, 1996).

Can predator presence partially mitigate impacts of high deer densities on human safety or property? We have few studies on wolves' influence on deer-vehicle collisions [but see chapter 2 in Raynor (2017) for a first assessment of a mitigating effect by wolves], but Gilbert et al. (2017) assembled evidence that cougars recolonizing the eastern U.S.A. for another 30 years could reduce deer-vehicle collisions by about $22 \%$, preventing over 20,000 human injuries, 155 fatalities, and $\$ 2+$ billion in costs. Adding in the value of avoided wildlife and human diseases or of reduced damage to forestry and agriculture that would result from lower deer densities might increase the potential value of predators by several times this. Such benefits of wolf presence on 
wildlife disease control have been recently documented (Tanner et al., 2019). In Bhutan, a study showed that the presence of an apex predator, the tiger (Panthera tigris), had indirect economic benefits through reduced losses in crops or livestock (Thinley et al., 2018). This benefit, however, must be balanced against the losses of human lives tigers can cause (Löe \& Röskaft, 2004). Another study in India documented that the presence of leopards (Panthera pardus) had indirect benefits to public health (Braczkowski et al., 2018). Such savings of life and property should be visible enough to bear on public discussions and decisions about how we manage wildlife. Better assessing the nature and extent of such beneficial effects in the context of recovering wolf populations in Europe and North America is challenging but needed.

\section{(3) The costs of wolf recovery}

Wolves have direct economic impacts on livestock farmers but incur little or no costs to urban citizens. The costs of wolf depredation to livestock in the Greater Yellowstone area is estimated to be $\$ 64,000 /$ year for a population of 300 wolves or about $\$ 210 /$ wolf/year (Duffield et al., 2006). Costs to livestock breeding have been estimated in other contexts (e.g. Bostedt \& Grahn, 2008). These analyses generally suggest that the direct economic costs of depredation by wolves are minor for the livestock sector as a whole but often substantial for individual livestock breeders (Muhly \& Musiani, 2009). These costs also extend beyond the simple market value of losing individual animals to include the sunk costs of past breeding efforts.

Not all livestock breeders are concerned by wolf attacks. Depredation of livestock varies with livestock species and breed. Wolf impacts tend to be relatively more important for sheep breeders grazing extensively in semi-natural habitats, and disproportionately more costly for small-scale sheep breeders whose flocks graze outside in bushy or forested areas (Mech et al., 2000; Treves et al., 2004). Costs are generally higher in places where wolves are coming back where livestock may represent up to half the prey items taken during the grazing season (Poulle, Carles \& Lequette, 1997). In other contexts, wolves feed mostly (>90\%) on wild prey (Smietana \& Klimek, 1993; Meriggi \& Lovari, 1996; Sidorovich, Tikhomirova \& Jedrzejewska, 2003; Capitani et al., $2004)$ with livestock representing $<5 \%$ of the consumed biomass. Once wolves become established, livestock depredation increases when and where wild prey are rare (Papageorgiou $e t$ $a l ., 1994)$. Where hunting and poaching reduce wild ungulate abundance, wolves can consume $>35 \%$ livestock (Sidorovich et al., 2003). This also increases human-wolf conflict (Linnell et al., 
2002; Sidorovich et al., 2003). In extreme cases where wolves have access to free-ranging cattle during the grazing season, the frequency of livestock in wolf scat can reach $45 \%$ and $>74 \%$ of the biomass consumed (Morehouse \& Boyce, 2011). Beyond these economic costs is the underlying perception by the rural people affected that the wider society imposes the recovery of a predator onto them and has little regard on their role or function in society and their values (Nilsson Dahlstrom, 2009; Eriksson, 2016a b).

The size and strength of wolves also make them a potential threat to human lives. Loss of human lives to wolves in the past has been thoroughly and critically examined (Löe \& Röskaft, 2004; Moriceau, 2011; Linnell \& Alleau, 2016). They were often linked to wolves infested by rabies. In contrast to what has been done for other species like brown bear (Ursus arctos) (Herrero, 2018), little effort has been made to study the conditions for wolf attacks on humans to occur in the current context, and, even more so, on how to respond in such an event to minimize the risk of a fatal outcome (Löe \& Röskaft, 2004; Linnell \& Alleau, 2016). Part of the reason is the current relatively rare incidence of attacks on humans in Europe and North America compared to fatalities caused by other wild animals (Linnell \& Alleau, 2016), or even by domestic animals such as dogs which caused an average of 17 human death/year in the U.S.A. and in excess of 1 death/year in Canada over study periods spanning two or more decades (Sacks et al., 1996; Avis, 1999; Raghavan, 2008).

As with benefits, wolves have many indirect costs that, in aggregate, could exceed their direct costs. These include the increased costs in time, money and energy that livestock breeders incur to defend their herds from wolves (Widman, Steen \& Elofsson, 2017). This additional workload extends to include psychological pressure. When wolves return to an area, livestock breeders must adopt new, or abandon old, practices. If more animals are herded into smaller areas, returning wolves could result in more overgrazing and soil compaction and under-grazing in other areas, influencing both pasture quality and flora (Meuret \& Provenza, 2014). Wolf attacks can also cause ewes to abort, decrease milk production, decrease appetite, increase stress, dismantle the flock structure, and result in the loss of herding dogs (Fritts \& Paul, 1989). Financial compensation for livestock destroyed by carnivores is usually met favourably (Naughton- Treves, Grossberg \& Treves, 2003), but its effectiveness has been questioned (Boitani, Ciucci \& Raganella-Pelliccioni, 2011). For herders accustomed to free-roaming husbandry in semi-natural landscapes, the return of wolves imposes a new external cost rarely 
acknowledged by those favouring the restoration of wolf populations (Muhly \& Musiani, 2009). The uneven spatial distribution of these costs is another level of uncertainty. It could however become an asset to help identify means of coexistence by analysing the mechanisms at work in areas with low or negligible losses (Breck, 2004; Espuno et al., 2004; Rigg et al., 2011). Hunters often claim that wolves reduce deer harvests. Such claims may be reasonable if wolves act to reduce deer densities substantially (Letnic \& Ripple, 2017), or if deer made wary by wolves are more difficult to shoot. Wolves were estimated to reduce deer harvests by hunters by 5-30\% in the Yellowstone ecosystem, appreciably less than was anticipated (Duffield et al., 2006). Direct effects of wolf predation on prey abundance has also been studied in Poland's Biełowieża forest. There, wolves killed and consumed on average 127 large ungulates per year versus 309 shot by hunters (Jędrzejewski et al., 2000). These combined losses reduced ungulate populations by less than $10 \%$, a value deemed unlikely to reduce hunting opportunities (Głowaciński \& Profus, 1997). Similar impacts and figures appear for North America (Kolenosky, 1972). Studies that explore the relative effects of wolf predation, climate, and hunting on prey populations often conclude that observed declines in deer populations more often reflect human harvest pressure than predation (Fuller, 1990). The impacts of wolves on deer populations also reflect habitat productivity (Crête, 1999) and the harshness of winters (Melis et al., 2009; Strickland, 2009). An intriguing ecological model (Kirchhoff \& Person, 2008) even goes so far as to suggest that despite the tendency for returning wolves to initially depress deer densities, resulting improvements in habitat conditions could boost resource levels enough to favour longterm recovery in the deer population as deer growth and reproduction improve. Thus, deer could recover to densities similar to those without wolves as overall ecosystem productivity improves. Wolves would then check further increases in deer density, preventing excessive browsing and sustaining high productivity. Such exercises emphasize the need for a long-term perspective and a deep understanding of underlying ecological dynamics.

\section{CHALLENGES AND WAYS FOREWARD}

\section{(1) Asymmetries in costs and benefits}

Thus far, we have documented that both deer and wolves can be seen as either beneficial or detrimental depending on the context and who is viewing them. Can challenges in living with deer or wolves be overcome by more completely identifying and tallying economic costs and 
benefits? At the moment, we see little effort to aggregate the economic costs and benefits of deer or wolves to encompass larger scales (county, national) or longer periods (many decades). A search for consensus on how to live with deer and predators is further complicated by the unequal distributions of costs and benefits that individual stakeholders experience. This unequal distribution can accentuate extreme feelings and misunderstandings about deer or wolves. For example, stakeholders directly suffering from deer or wolves (e.g. farmers, foresters, hunters or livestock breeders) see clear benefits in reducing their populations. Farmers or foresters often suffer significant direct economic losses from abundant deer populations (see Section III). However, farmers or foresters who hunt deer or receive revenues from leasing private or public land to hunters can be inclined to accept a trade-off between having more deer and losing more from those deer. The nature of this trade-off deserves further exploration (but see Goodale, Parsons \& Sherren, 2015). In the absence of associated benefits, the notion of a trade-off is beyond reach for livestock breeders and/or hunters when it includes direct losses due to wolves or carnivores (Skogen \& Krange, 2003; Goodale et al., 2015).

While direct benefits and costs from large deer populations are easy to perceive, others, such as their direct and indirect impacts on biodiversity or human health and safety, are harder to quantify and reveal. With wolves, this asymmetry in perceiving costs and benefits is radical. Direct costs such as livestock destruction are easy to perceive. They are economical and psychological. Benefits of restored wolf populations for biodiversity, forestry, tourism, human health and human lives (reduced road casualties through restored carnivore populations) etc. are all indirect, difficult to assess and time-consuming to identify and quantify. They are thus easy to minimize or overlook.

The asymmetry in our ability to quantify and to perceive costs or benefits complicates any assessment of the full scope of the problem by stakeholders and the public. It certainly plays a role in explaining why human attitudes towards deer or wolf recovery tend to be polarized, opposing (easily perceived) benefits of one species against the (easily perceived) costs caused by the other (Fig. 3A, D). This is amplified by the natural tendency of any given group of stakeholders to emphasize evidence that confirms their perspective while discounting or ignoring conflicting evidence (Nickerson, 1998). 


\section{(2) Acceptance versus conflict, a matter of time, place and species}

Deer generally benefit from a broad level of sympathy across the general population (Nelson, 1998). However, situations of high abundance, especially in suburban areas and in areas with deer-sensitive crops, together with an increasing awareness of the potential harm that high deer populations can cause to resources, property, health and lives, has led to more contrasting attitudes towards their presence (Warren, 1997; Storm et al., 2007). Cognitive dissonance emerges starkly in a survey of Pennsylvania hunters (Diefenbach, Palmer \& Shope, 1997). A vast majority of hunters (87\%) acknowledged that high deer densities impaired forest integrity, meaning that controlling deer populations was necessary to keep deer in balance with their food supply and with local plant and animal communities. Nevertheless, a majority of these same hunters disagreed that deer damage to local forests was a problem, instead expressing the opinion that deer populations were too low and that permits for antlerless deer should be reduced or eliminated.

In the same region, a survey of agricultural producers and homeowners revealed a direct link between the level of damage they experienced and the perception of deer as a nuisance (West $\&$ Parkhurst, 2002). Surveys of the general public showed strong support for deer abundance control to avoid threats to human health or safety or environmental damage, but control was judged less acceptable when it was aimed at reducing aesthetic impacts or personal property damage (Fulton et al., 2004). Among Scottish recreational hunters, resistance to regulating soaring deer populations, a reluctance rooted in hunting tradition or personal preferences, was reinforced by antipathy to conservationists (MacMillan \& Leitch, 2008).

These examples, related to increasing deer populations, illustrate how personal perspectives influence our ability to envision co-existence strategies based on objective analyses of costs and benefits. Lacking solid numbers for these costs and benefits only amplifies the importance of personal beliefs (sensu Dandy et al., 2012).

When it comes to the presence of wolves, the level of conflict and tension is orders of magnitude more acute. Although a significant fraction of the population perceives their presence as positive (Jacobsen \& Linnell, 2016; Treves \& Bonacic, 2016), those who most favour their presence are often those who interact the least with them. Positive attitudes towards wolves can decline once wolves become present in an area (Williams, Ericsson \& Heberlein, 2002; Dressel, Sandström \& Ericsson, 2015). In a context of an increasing wolf population in the midwest U.S.A., attitudes of 
a selected group of citizens became more negative and fearful over time, independently of having been subjected to wolf impact (Treves, Naughton- Treves \& Shelley, 2013). Around Yellowstone National Park, although no net change occurred in the generally positive attitudes people held toward wolves after their introduction, attitudes became more polarized. Support for wolves especially decreased among visitors to the Park who were hunters or ranchers (Duffield et al., 2006). In some instances however, people initially unsympathetic to wolves developed more positive attitudes as their knowledge about wolves increased, often via direct interactions with them (Ericsson \& Heberlein, 2003; Bisi et al., 2007).

The opposition to wolves, based on livestock depredation, recorded in the midwest U.S.A. contrasts with the tolerance towards black bears in the same region, even though bears caused almost three times as much depredation to livestock (Treves \& Karanth, 2003; see also Bangs \& Shivik, 2001). Paradoxically, wolves were also the first species listed as endangered in the U.S.A. (Sharpe, Norton \& Donnelley, 2001).

\section{(3) Lethal control, a source of conflict}

Resorting to lethal control of wildlife is where opposition in opinions seems most acute. Culling wild deer in Europe or North America often triggers strong reactions from stakeholders and the public. Whether individuals support or oppose deer culling often depends on their perceptions and the particular impacts being considered, or on the ultimate cause of deer overabundance (Dandy et al., 2012). Reactions to lethal wolf control are most polarized: lethal control is seen as the only real option for some, yet as totally unacceptable for others (Dandy et al., 2012). On the surface, the rationale is to eliminate a competitor or taker of livestock or game. When livestock depredation is the concern, lethal control is often seen as preferable to prevention measures [e.g. Mech (2001); but see Musiani et al. (2003), Gehring, VerCauteren \& Landry (2010), Gehring et al. (2011), Urbigkit \& Urbigkit (2010) and Degeorges \& Lalo (2017)], although its efficiency as currently practiced relative to non-lethal methods has been questioned (Treves, Krofel \& McManus, 2016; but see Redpath et al. 2017) and should be investigated further (van Eeden et al., 2018; Treves et al., 2017. In Sweden, lethal control to reduce impact on livestock was widely accepted, but hunting wolves for other reasons was only advocated by a minority (Ericsson et al., 2004). In herders, the idea of lethal control often correlates with the notion of "wolves not in my backyard' emphasizing the local spatial component. Among politicians, lethal control is often 
conceived as a means to increase tolerance, but the emphasis can also be on controlling the development of poaching (Doré, 2011; Linnell, Trouwborst \& Fleurke, 2017). The potential for an actual opposing effect on poaching has been proposed but challenged (Chapron \& Treves, 2016; Pepin, Kay \& Davis, 2017).

For people who favour protecting deer and wolves as a coevolved interacting system, or are in favour of more ethical relationships with non-human life, 'control' is perceived as another instance of abusive interference of humans with 'wild', i.e. 'self-willed' nature, where animals exist for themselves in their own right [see Foreman (2004) and Morizot (2016)].

\section{(4) Differences in values and the value of disagreement}

How opposing groups of concerned stakeholders interact will depend on the degree to which each group accepts and understands the challenges, constraints, and value system of other groups (Jacobsen \& Linnell, 2016). This can be made more difficult if opinion leaders use humanwildlife conflicts as a vehicle to promote their own political agendas (Pulliainen et al., 1999; Skogen \& Krange, 2003).

Ultimately, resolution of these disputes will hinge on how much trust each group can grant to the knowledge of other groups (Brainerd \& Bjerke, 2002; Bisi et al., 2007). Somewhat counterintuitively, developing such trust fundamentally requires that all stakeholders first agree on their disagreement, rather than trying to resolve their differences in opinion prior to working together. The recognition of fundamentally different viewpoints should be seen as a necessary preliminary step rather than making human-wolf conflict even more unsolvable [assuming that all parties agree to respect their disagreements (Bisi et al., 2007)]. The common ground of accepted disagreement recognizes and bridges distinct world views, providing the basis for working together towards the mitigation of specific and consensual problems posed by living with wild animals. This collaborative process could, over time, erode entrenched emotions and opposing points of view and pave the way to less polarized attitudes by focusing on common visions obscured by distrust or patronizing (e.g. see Skogen, 2003 or Redpath et al., 2017, and references therein. For conservationists, 'is lethal control of wolves acceptable if it aims at reducing the propensity of wolves to attack livestock?' could then become a valid question. For herders 'how many losses from wolves, compensated financially by tax money, are acceptable when considering their positive effects on decreasing deer damage to society?' also could become an 
acceptable question. For hunters it would be about defining an acceptable reduction in game abundance or accessibility in light of the costs of deer presence to agriculture, forestry or public safety or in light of wolf sport hunting opportunities. For politicians it could be to accept that the question is not a binary one as, for example, accepting or not the presence of wolves, but of defining viable terms of coexistence, as they do, for example, for another high-liability component of our societies, the individual car.

\section{(5) A need for a broader perspective?}

Controversies, whether concerning living with deer or with wolves, often seem bogged in essentialisms in the sense that species are seen as uniform entities in need of technical 'control', rather than as an ensemble of sentient individual beings. Herders, hunters, environmentalists, scientists tend also to be considered as uniform entities in which individuals are uniform vehicles of simple truths devoid of judgment autonomy (e.g. see Skogen \& Krange, 2003).

To date, the portraying of a radical headlock opposing 'herders' to 'conservationists' about the presence of wolves has occupied the frontstage and front pages while controversies about ungulate abundance were left backstage (Mounet, 2007). Given the wide range of deer impacts, their sometimes dramatic consequences on human lives, and the potential for carnivores to limit these impacts, we wonder why the legitimate concerns and distress of livestock herders or those of hunters so consistently capture the spotlight. At some point, the far-reaching consequences deer have for land managers, foresters, health care providers, the insurance industry, and citizens concerned for their health and road safety must also count, as well as the potential influence wolves may have on the above.

\section{DISCUSSION}

\section{(1) Top concerns for a way forward}

We have reviewed how the relatively narrow visions that often dominate debates over deer and wolf management neglect the intertwined consequences that concern much broader segments of society. We suggest a corresponding need to consider a far wider set of perspectives as we address the questions of how best to interact with deer and predator populations. The top concerns for future research on these questions should be to approach better in an integrative 
way: (1) the ecological and sociological mechanisms behind increases in deer populations, (2) the ecological and sociological mechanisms that drive changes in wolf distribution and abundance, (3) the full consequences on our lives of these related dynamics, and (4) how to maximize aggregate benefits and minimize the collective costs incurred when we interact with deer and wolves as parts of integrated ecosystems subject to long-term dynamics. While an integrative approach in concerns (1) and (2) can build on a broad knowledge base, concerns (3) and (4) will pose real challenges even in the acquisition of the basic knowledge needed for an integrative approach.

\section{(2) Obstacles to overcome}

This broader and more integrated approach, which, we feel, is still lacking both in the research, political and public sphere, will have to overcome the apparent entrenched attitudes and conflicting values attributed to what are perceived as opposing homogenous groups. This would allow the ambivalence and mixed feelings running within these groups to emerge and enrich the debate, despite and beyond the perceived need for loyalty towards social boundaries constructed to confront those perceived as adversaries (Skogen \& Krange, 2003). It would also bring to the forefront the question of mutual respect and understanding of differences in values and opinions among those involved (Redpath et al., 2013, 2017; Jacobsen \& Linnell, 2016). In short, there is a need to (1) make a better effort to cost/quantify the indirect effects of wolves and deer; (2) encourage conflict resolution by opposing sides respectfully accepting their disagreements; and (3) understand the cultural motivations of dislikes to work out the causal reason not the proximal reason for conflicts (e.g. people feeling that they are not respected).

\section{(3) From conflict to coexistence}

We must acknowledge that people within different groups not only differ in the values they hold most dear but also that they bear different valued elements of knowledge that must be shared as we seek viable solutions. If coexistence is the goal aimed for, we need deer and wolves to persevere in ways that are compatible with human interests. At the same time, human interests would have to be conceived in ways that do not threaten the continued existence of deer and wolves. Morizot (2016) suggests that instead of focusing on one side over another (deer, wolves, 
sheep herders, hunters, environmentalists, etc.), we could instead focus on how to achieve a workable network of ecological and sociological interactions among these components. Steps towards a more balanced socio-ecological approach are emerging (e.g. Skogen, 2003; Treves \& Karanth, 2003; Dickman, 2010). Loud voices will continue to polarize the debate as changes in human attitudes and cultural learning take time, but they do occur. As these emerge, our ecological interactions with deer and wolves will be reshaped.

\section{CONCLUSIONS}

(1) Historically, deer (cervid) and wolf populations in North America and Western Europe declined greatly until the $20^{\text {th }}$ century at which point they began to recover dramatically in terms of geographic range and abundance. Deer recoveries reflect scarce predators and dramatic changes in hunting policies and land use. Wolf recoveries reflect both legal protection and responses to rising deer numbers but remain less complete.

(2) Current high deer densities are having many ecological, economic, and social effects but these are perceived differentially by different stakeholders. Deer have both direct effects on tree regeneration, natural vegetation, and planted crops and many indirect effects via their impacts on plant and animal communities, diseases and parasites of humans and wildlife, and on vehicular accidents. Where deer populations lack control, these collective and cumulative impacts can be large.

(3) The recovery of wolf populations also has ecological, economic, and social effects that affect various human groups quite differently. Although controversies persist over trophic cascades, wolves have considerable potential to mitigate negative impacts of deer via both direct effects on their populations and indirect effects on their movement and behavior. Top-down beneficial effects of wolves include their ability to mitigate deleterious impacts of deer on forestry, agriculture, tourism, and natural ecosystems and to improve human and wildlife health and safety. Wolves might even relieve deer browsing enough to improve habitat conditions and actually sustain more deer. Such tri-trophic cascades may be common but are difficult to detect and demonstrate, sustaining controversies. 
(4) Further controversy results from the fact that benefits from wolves are hard to measure and rarely fully accounted for, meaning they are rarely weighed fairly against the more obvious impacts wolf populations have on certain rural groups dependent on livestock operations or deer hunting. Contrasting views on the relative costs and benefits of deer and wolves sustain strong sentiments and controversy.

(5) We need to aggregate and evaluate the costs and benefits of deer and wolves across larger scales (county, national) and longer periods (many decades). Even this necessary effort, however, is unlikely to yield a consensus on how to coexist with deer and wolves as different stakeholders perceive different costs and benefits. This difficulty is compounded for deer as their direct benefits are easily perceived while the several costs they incur are often indirect, delayed, and dispersed among many parties. In contrast, costs for wolves are easily perceived while their benefits are often indirect and difficult to document. This asymmetry tends to polarize human attitudes. Our review shows that human attitudes toward wolves can shift over time and among regions from conflict to acceptance when conflicts can be resolved through collaborative approaches that respect differences in values.

(6) We face continuing concerns and obstacles as we move forward from conflict to coexistence. Integrative approaches that respect and enumerate a full range of values are more likely to succeed. Although such approaches remain rare, progress is possible if we recognize deer, wolves, and their habitats as a coupled system and highlight the aggregate benefits to be achieved while minimizing costs to affected human groups.

\section{ACKNOWLEDGEMENTS}

We thank Nicolas Lescureux and Marie Chandelier for stimulating discussions on this challenging subject and two anonymous reviewers for their pertinent suggestions.

\section{REFERENCES}

AdLeR, G.H., Telford, S.R., WILSON, M.L. \& SPIELMAN, A. (1992) Vegetation structure influences the burden of immature Ixodes dammini on its main host, Peromyscus leucopus.

Parasitology 105, 105-110. 
Albert, A., Auffret, A.G., Cosyns, E., Cousins, S.A., D’hondt, B., Eichberg, C., Eycott, A.E., Heinken, T., HofFMANN, M. \& JAROSZEWICZ, B. (2015) Seed dispersal by ungulates as an ecological filter: a trait-based meta-analysis. Oikos 124, 1109-1120.

AlLAN, B.F., KeEsing, F. \& Ostfeld, R.S. (2003) Effect of forest fragmentation on Lyme disease risk. Conservation Biology 17, 267-272.

AlleAu, J. \& LinnelL, J.D. (2015) The story of a man-eating beast in Dauphiné, France (1746-1756). The White Horse Press.

Allombert, S., Gaston, A.J. \& MARTin, J.-L. (2005a) A natural experiment on the impact of overabundant deer on songbird populations. Biological Conservation 126, 1-13.

Allombert, S., StockTon, S.A. \& MARTin, J.-L. (2005b) A Natural Experiment on the Impact of Overabundant Deer on Forest Invertebrates. Conservation Biology 19, 1917-1929.

Apollonio, M., Andersen, R. \& Putman, R. (2010) European ungulates and their management in the 21st century. Cambridge University Press.

Augustine, D.J. \& DeCALESTA, D. (2003) Defining deer overabundance and threats to forest communities: from individual plants to landscape structure. Ecoscience 10, 472-486.

Augustine, D.J. \& FreliCH, L.E. (1998) Effects of white-tailed deer on populations of an understory forb in fragmented deciduous forests. Conservation Biology 12, 995-1004.

Augustine, D.J., FreliCH, L.E. \& JoRdAN, P.A. (1998) Evidence for two alternate stable states in an ungulate grazing system. Ecological Applications 8, 1260-1269.

AVIS, S.P. (1999) Dog pack attack: hunting humans. The American journal of forensic medicine and pathology 20, 243-246.

BAINES, D., SAGE, R.B. \& BAINES, M.M. (1994) The implications of red deer grazing to ground vegetation and invertebrate communities of Scottish native pinewoods. Journal of Applied Ecology 31, 776-783.

BAISER, B., LOCKWOOD, J.L., LA PUMA, D. \& ARONSON, M.F.J. (2008) A perfect storm: two ecosystem engineers interact to degrade deciduous forests of New Jersey. Biological Invasions 10, 785-795.

BALGOOYEN, C.P. (1995) The use of Clintonia borealis and other indicators to gauge impacts of white-tailed deer on plant communities in northern Wisconsin, USA. Natural Areas Journal 15, 308-318.

BANGS, E. \& SHIVIK, J.A. (2001) Managing wolf conflict with livestock in the northwestern United States. USDA National Wildlife Research Center-Staff Publications. 
BASHORE, T.L., TZILKOWSKI, W.M. \& BelLIS, E.D. (1985) Analysis of deer-vehicle collision sites in Pennsylvania. The Journal of Wildlife Management 49, 769-774.

BECK, J.L. \& PEEK, J.M. (2005) Diet composition, forage selection, and potential for forage competition among elk, deer, and livestock on aspen-sagebrush summer range. Rangeland Ecology \& Management 58, 135-147.

Benestad, S.L., Mıtchell, G., Simmons, M., Ytrehus, B. \& VikØRen, T. (2016) First case of chronic wasting disease in Europe in a Norwegian free-ranging reindeer. Veterinary research 47, 88.

BISI, J., KURKI, S., SVEnSBERG, M. \& LIUKKONEN, T. (2007) Human dimensions of wolf (Canis lupus) conflicts in Finland. European Journal of Wildlife Research 53, 304-314.

BLANCO, J.C. \& CORTES, Y. (2001) Impact of barriers on a wolf (Canis lupus) population in an agricultural environment in Spain. In Proceedings of the International Conference on Ecology and Transportation, Keystone, CO, September 24-28, 2001 p. 517. Keystone Colorado.

BOITANI, L. (1995) Ecological and cultural diversities in the evolution of wolf-human relationships. In Ecology and conservation of wolves in a changing world. (eds L.N. CARBYN, S.H. FRITTS \& D.R. SEIP), pp. 3-12Canadian Circumpolar Institute. Edmonton, Alberta, Canada.

BoitANI, L., CiuCCI, P. \& RAgAnella-PellicCIONI, E. (2011) Ex-post compensation payments for wolf predation on livestock in Italy: a tool for conservation? Wildlife Research 37, 722-730.

BoITANI, L. \& LINNELL, C.J.D. (2015) Bringing Large Mammals Back: Large Carnivores in Europe. In Rewilding European Landscapes (eds M.H. PereIRA \& M.L. NAVARRO), pp. 67-84. Springer International Publishing, Cham.

BOSTEDT, G. \& GRAHN, P. (2008) Estimating cost functions for the four large carnivores in Sweden. Ecological Economics 68, 517-524.

Boulanger, V., Baltzinger, C., Saïd, S., Ballon, P., Picard, J.-F. \& Dupouey, J.-L. (2015) Decreasing deer browsing pressure influenced understory vegetation dynamics over 30 years. Annals of Forest Science 72, 367-378.

Braczkowski, A.R., O’Bryan, C.J., Stringer, M.J., Watson, J.E., Possingham, H.P. \& Beyer, H.L. (2018) Leopards provide public health benefits in Mumbai, India. Frontiers in Ecology and the Environment 16, 176-182.

BRADSHAW, L. \& WALLER, D.M. (2016) Impacts of white-tailed deer on regional patterns of forest tree recruitment. Forest Ecology and Management 375, 1-11. 
BRAINERD, S. \& BJERKE, T. (2002) Reports for the large predator policy statement. Information measures relative to large carnivores in Norway. Norwegian Institute for Nature Research. Fagrapport 69, 71.

BRECK, S.W. (2004) Minimizing carnivore-livestock conflict: the importance and process of research in the search for coexistence. People and predators: from conflict to coexistence, 13-17.

BURBAItÉ, L. \& CSANYI, S. (2009) Roe deer population and harvest changes in Europe. Estonian Journal of Ecology 58, 169-180.

BYERS, J.A. (1997) American pronghorn: social adaptations and the ghosts of predators past. University of Chicago Press, Chicago, London.

Cairns, V., Wallenhorst, C., Rietbrock, S. \& Martinez, C. (2019) Incidence of Lyme disease in the UK: a population-based cohort study. BMJ open 9, e025916.

Callan, R., Nibbelink, N.P., Rooney, T.P., Wiedenhoeft, J.E. \& WydeVen, A.P. (2013) Recolonizing wolves trigger a trophic cascade in Wisconsin (USA). Journal of Ecology 101, 837-845.

Capitani, C., Bertelli, I., Varuzza, P., Scandura, M. \& Apollonio, M. (2004) A comparative analysis of wolf (Canis lupus) diet in three different Italian ecosystems. Mammalian BiologyZeitschrift für Säugetierkunde 69, 1-10.

CAUGHLEY, G. (1970) Eruption of ungulate populations, with emphasis on Himalayan thar in New Zealand. Ecology 51, 53-72.

Caughley, G. (1983) The deer wars: the story of deer in New Zealand. Heinemann, Aukland.

Ceballos, G., Ehrlich, P.R. \& Dirzo, R. (2017) Biological annihilation via the ongoing sixth mass extinction signaled by vertebrate population losses and declines. Proceedings of the National Academy of Sciences 114, E6089-E6096.

Chamaillé-Jammes, S., Malcuit, H., Le Saout, S. \& Martin, J.-L. (2014) Innate threat-sensitive foraging: black-tailed deer remain more fearful of wolf than of the less dangerous black bear even after 100 years of wolf absence. Oecologia 174, 1151-1158.

Chapron, G., Kaczensky, P., Linnell, J.D.C., von ArX, M., Huber, D., Andren, H., Vicente Lopez-Bao, J., Adamec, M., Alvares, F., Anders, O., Balciauskas, L., Balys, V., Bedo, P., Bego, F., Carlos BLANCO, J., ET AL. (2014) Recovery of large carnivores in Europe's modern humandominated landscapes. Science 346, 1517-1519.

ChAPRON, G. \& TREVES, A. (2016) Blood does not buy goodwill: allowing culling increases poaching of a large carnivore. In Proc. R. Soc. B p. 20152939. The Royal Society. 
Chips, M.J., Yerger, E.H., Hervanek, A., Nuttle, T., Royo, A.A., Pruitt, J.N., McGlynn, T.P., Riggall, C.L. \& CARSON, W.P. (2015) The Indirect Impact of Long-Term Overbrowsing on Insects in the Allegheny National Forest Region of Pennsylvania. Northeastern Naturalist 22, 782797.

Chollet, S. \& MARTIN, J.-L. (2013) Declining woodland birds in North America: should we blame Bambi? Diversity and Distributions 19, 481-483.

Chollet, S., Padié, S., Stockton, S., Allombert, S., Gaston, A.J. \& Martin, J.-L. (2016) Positive plant and bird diversity response to experimental deer population reduction after decades of uncontrolled browsing. Diversity and Distributions 22, 274-287.

Christianson, D. \& CREEL, S. (2008) Risk effects in elk: sex-specific responses in grazing and browsing due to predation risk from wolves. Behavioral Ecology 19, 1258-1266.

ChRISTIANSON, D. \& CREEL, S. (2010) A nutritionally mediated risk effect of wolves on elk. Ecology 91, 1184-1191.

Clutton-Brock, T.H., Coulson, T. \& Milner, J.M. (2004) Red deer stocks in the Highlands of Scotland. Nature 429, 261.

ColinvauX, P.A. (1979) Why big fierce animals are rare: an ecologist's perspective. Princeton University Press, Princeton, New Jersey.

Cordain, L., Eaton, S.B., Brand Miller, J., ManN, N. \& Hill, K. (2002) The paradoxical nature of hunter-gatherer diets: Meat-based, yet non-atherogenic. European journal of clinical nutrition 56, S42.

CÔtÉ, S.D., Rooney, T.P., Tremblay, J.-P., Dussault, C. \& Waller, D.M. (2004) Ecological Impacts of Deer Overabundance. Annual Review of Ecology, Evolution, and Systematics 35, 113-147.

CREel, S. \& Christianson, D. (2008) Relationships between direct predation and risk effects. Trends in Ecology \& Evolution 23, 194-201.

Creel, S., Winnie, J.A., Christianson, D. \& Liley, S. (2008) Time and space in general models of antipredator response: tests with wolves and elk. Animal Behaviour 76, 1139-1146.

CRÊTE, M. (1999) The distribution of deer biomass in North America supports the hypothesis of exploitation ecosystems. Ecology Letters 2, 223-227.

Dandy, N., Ballantyne, S., Moseley, D., Gill, R., Quine, C. \& Van Der Wal, R. (2012) Exploring beliefs behind support for and opposition to wildlife management methods: a qualitative study. European Journal of Wildlife Research 58, 695-706.

DÁvalos, A., Nuzzo, V. \& Blossey, B. (2015) Single and interactive effects of deer and earthworms on non-native plants. Forest Ecology and Management 351, 28-35. 
Deblinger, R.D., WiLson, M.L., Rimmer, D.W. \& SPIELMAN, A. (1993) Reduced abundance of immature Ixodes dammini (Acari: Ixodidae) following incremental removal of deer. Journal of Medical Entomology 30, 144-150.

DECALESTA, D.S. (1994) Effect of white-tailed deer on songbirds within managed forests in Pennsylvania. The Journal of Wildlife Management 58, 711-718.

Degeorges, P. \& Lalo, A. (2017) L'acceptabilité sociale des tirs de loups. Histoire \& Sociétés Rurales 47, 99-136.

DeLIBES, M. (1990) Status and conservation needs of the wolf (Canis lupus) in the Council of Europe member states. Council of Europe Member States, Council of Europe, Strasbourg.

DICKMAN, A.J. (2010) Complexities of conflict: the importance of considering social factors for effectively resolving human-wildlife conflict. Animal conservation 13, 458-466.

Diefenbach, D.R., Palmer, W.L. \& Shope, W.K. (1997) Attitudes of Pennsylvania sportsmen towards managing white-tailed deer to protect the ecological integrity of forests. Wildlife Society Bulletin 25, 244-251.

DONADIO, E. \& BUSKIRK, S.W. (2016) Linking predation risk, ungulate antipredator responses, and patterns of vegetation in the high Andes. Journal of Mammalogy 97, 966-977.

DORE, A. (2011) Des loups dans la cité: éléments d’écologie pragmatiste. ULiège, Liège, Belgique.

Drompr, M.R. (2011) The Lone Wolf in Inner Asia. Journal of the American Oriental Society 131, 515-526.

Duffield, J., Neher, C. \& PAtTerson, D. (2006) Wolves and people in Yellowstone: Impacts on the regional economy. In p. 67. Yellowstone Park Foundation.

DUfFUS, D.A. \& DEARDEN, P. (1990) Non-consumptive wildlife-oriented recreation: a conceptual framework. Biological Conservation 53, 213-231.

van Eeden, L.M., Eklund, A., Miller, J.R., Lopez-Bao, J.V., Chapron, G., Cejtin, M.R., Crowther, M.S., DickMAN, C.R., FrANK, J. \& KROFEL, M. (2018) Carnivore conservation needs evidence-based livestock protection. PLoS biology 16, e2005577.

EnSERINK, M. \& Vogel, G. (2006) The Carnivore Comeback. Science 314, 746-749.

ERICSSON, G. \& HeBerLein, T.A. (2003) Attitudes of hunters, locals, and the general public in Sweden now that the wolves are back. Biological Conservation 111, 149-159.

Ericsson, G., Heberlein, T.A., Karlsson, J., BjÄrvall, A. \& Lundvall, A. (2004) Support for hunting as a means of wolf Canis lupus population control in Sweden. Wildlife Biology 10, 269-276. 
ERIKSSON, M. (2016a) Changing attitudes to Swedish wolf policy: wolf return, rural areas, and political alienation. Umeå universitet.

ERIKSSON, M. (2016b) Rurality and collective attitude effects on wolf policy. Sustainability 8, 711.

Espuno, N., Lequette, B., Poulle, M.-L., Migot, P. \& Lebreton, J.-D. (2004) Heterogeneous response to preventive sheep husbandry during wolf recolonization of the French Alps. Wildlife Society Bulletin 32, 1195-1208.

Finder, R.A., RoseberRy, J.L. \& WoOlf, A. (1999) Site and landscape conditions at white-tailed deer/vehicle collision locations in Illinois. Landscape and Urban Planning 44, 77-85.

Fischer, A., Selge, S., VAn Der WAL, R. \& LARSON, B.M. (2014) The public and professionals reason similarly about the management of non-native invasive species: a quantitative investigation of the relationship between beliefs and attitudes. PloS one 9, e105495.

FLADER, S.L. (1974) Thinking like a mountain: Aldo Leopold and the evolution of an ecological attitude toward deer, wolves, and forests. Univ of Missouri Press, Columbia, USA.

FlaGel, D.G., Belovsky, G.E. \& Beyer, D.E. (2016) Natural and experimental tests of trophic cascades: gray wolves and white-tailed deer in a Great Lakes forest. Oecologia 180, 1183-1194.

FoltZ, R. (2010) Zoroastrian attitudes toward animals. Society \& Animals 18, 367-378.

FoRD, A.T. \& GoHeEn, J.R. (2015) Trophic Cascades by Large Carnivores: A Case for Strong Inference and Mechanism. Trends in ecology \& evolution 30, 725-735.

ForemAN, D. (2004) Rewilding North America: a vision for conservation in the 21st century. Island Press, Washington, Covelo, London.

Fortin, D., Beyer, H.L., Boyce, M.S., SMith, D.W., DuChesne, T. \& MAO, J.S. (2005) Wolves influence elk movements: behavior shapes a trophic cascade in Yellowstone National Park. Ecology 86, 1320-1330.

FRITTS, S.H., BANGS, E.E. \& GORE, J.F. (1994) The relationship of wolf recovery to habitat conservation and biodiversity in the northwestern United States. Landscape and Urban Planning 28, 23-32.

FRITTS, S.H. \& PAUL, W.J. (1989) Interactions of wolves and dogs in Minnesota. Wildlife Society Bulletin (1973-2006) 17, 121-123.

FULLER, R.J. (2001) Responses of woodland birds to increasing numbers of deer: a review of evidence and mechanisms. Forestry 74, 289-298. 
FULLER, R.J. \& GILL, R.M.A. (2001) Ecological impacts of increasing numbers of deer in British woodland. Forestry 74, 193-199.

FulLER, T.K. (1990) Dynamics of a Declining White-Tailed Deer Population in North-Central Minnesota. Wildlife Monographs 110, 3-37.

Fulton, D.C., SkERL, K., Shank, E.M. \& LIME, D.W. (2004) Beliefs and attitudes toward lethal management of deer in Cuyahoga Valley National Park. Wildlife Society Bulletin 32, 1166-1176.

Gehring, T.M., VerCaUteren, K.C. \& LANDRY, J.-M. (2010) Livestock protection dogs in the 21st century: is an ancient tool relevant to modern conservation challenges? BioScience 60, 299-308.

Gehring, T.M., VerCauteren, K.C., Provost, M.L. \& Cellar, A.C. (2011) Utility of livestockprotection dogs for deterring wildlife from cattle farms. Wildlife Research 37, 715-721.

GEIST, V. (1998) Deer of the world: their evolution, behaviour, and ecology. Stackpole books, Mechanicsburg, $\mathrm{Pa}$.

Gilbert, S.L., Sivy, K.J., Pozzanghera, C.B., DuBour, A., Overduijn, K., Smith, M.M., Zhou, J., Little, J.M. \& PRUGH, L.R. (2017) Socioeconomic Benefits of Large Carnivore Recolonization Through Reduced Wildlife-Vehicle Collisions. Conservation Letters 10, 431-439.

GŁoWACIŃSKI, Z. \& Profus, P. (1997) Potential impact of wolves Canis lupus on prey populations in eastern Poland. Biological Conservation 80, 99-106.

GoOdAle, K., PARSONS, G.J. \& SherREN, K. (2015) The Nature of the Nuisance-Damage or ThreatDetermines How Perceived Monetary Costs and Cultural Benefits Influence Farmer Tolerance of Wildlife. Diversity 7, 318-341.

HABER, G.C. (1996) Biological, conservation, and ethical implications of exploiting and controlling wolves. Conservation Biology 10, 1068-1081.

HAIRSTON, N.G., SMith, F.E. \& SLOBOtKIn, L.B. (1960) Community structure, population control, and competition. American Naturalist 94, 421-425.

HAMPTON, B. (1997) The great American wolf. Macmillan.

HARRISON, K.A. \& BARDGETT, R.D. (2004) Browsing by red deer negatively impacts on soil nitrogen availability in regenerating native forest. Soil Biology and Biochemistry 36, 115-126.

Henderson, J. \& MoORE, S. (2006) The capitalization of wildlife recreation income into farmland values. Journal of agricultural and applied economics 38, 597-610. 
Hermann, N., Voß, C. \& Menzel, S. (2013) Wildlife value orientations as predicting factors in support of reintroducing bison and of wolves migrating to Germany. Journal for Nature Conservation 21, 125-132.

HERRERO, S. (2018) Bear attacks: their causes and avoidance. Rowman \& Littlefield, Lanham, MD.

Horsley, S.B., Stout, S.L. \& DeCalestA, D.S. (2003) White-tailed deer impact on the vegetation dynamics of a northern hardwood forest. Ecological Applications 13, 98-118.

Hothorn, T., BrandL, R. \& Müller, J. (2012) Large-scale model-based assessment of deer-vehicle collision risk. PloS one 7, e29510.

IIDA, T., SOGA, M., HIURA, T. \& KOIKE, S. (2016) Life history traits predict insect species responses to large herbivore overabundance: a multitaxonomic approach. Journal of insect conservation 20, 295-304.

JACOBSEN, K.S. \& LINNELL, J.D. (2016) Perceptions of environmental justice and the conflict surrounding large carnivore management in Norway-Implications for conflict management. Biological Conservation 203, 197-206.

JȨDRZEJeWSKI, WŁ., JȩdRZEJeWSKA, B., OKarma, H., Schmidt, K., ZuB, K. \& Musiani, M. (2000) Prey selection and predation by wolves in Białowieża Primeval Forest, Poland. Journal of Mammalogy 81, 197-212.

Johnson, C.J., Pedersen, J.A., Chappell, R.J., McKenzie, D. \& Aiken, J.M. (2007) Oral transmissibility of prion disease is enhanced by binding to soil particles. PLoS Pathogens 3, e93.

JORDAN, R.A., SchulzE, T.L. \& JAHN, M.B. (2007) Effects of reduced deer density on the abundance of Ixodes scapularis (Acari: Ixodidae) and Lyme disease incidence in a northern New Jersey endemic area. Journal of medical entomology 44, 752-757.

KARBAN, R. \& BALDWIN, I.T. (1997) Induced responses to herbivory University of Chicago Press. Chicago, Illinois, USA.

KaUfFMAN, M.J., BRodie, J.F. \& JULES, E.S. (2010) Are wolves saving Yellowstone's aspen? A landscape-level test of a behaviorally mediated trophic cascade. Ecology 91, 2742-2755.

KILPATRICK, H.J., LABONTE, A.M. \& STAFFORD, K.C. (2014) The relationship between deer density, tick abundance, and human cases of Lyme disease in a residential community. Journal of medical entomology 51, 777-784.

KNIGHT, T.M., DunN, J.L., SMITH, L.A., DAVIS, J. \& KALISZ, S. (2009) Deer facilitate invasive plant success in a Pennsylvania forest understory. Natural Areas Journal 29, 110-116.

Kolenosky, G.B. (1972) Wolf Predation on Wintering Deer in East-Central Ontario. The Journal of Wildlife Management 36, 357-369. 
KUiJPer, D.P.J., De Kleine, C., Churski, M., Van Hooft, P., Bubnicki, J. \& JęDRZejewska, B. (2013) Landscape of fear in Europe: wolves affect spatial patterns of ungulate browsing in Białowieża Primeval Forest, Poland. Ecography 36, 1263-1275.

KuiJPer, D.P.J., Sahlén, E., Elmhagen, B., Chamaillé-Jammes, S., Sand, H., Lone, K. \& Cromsigt, J. (2016) Paws without claws? Ecological effects of large carnivores in anthropogenic landscapes. Proc. R. Soc. B 283.

LAngbein, J., PutMan, R.J. \& Pokorny, B. (2011) Traffic collisions involving deer and other ungulates in Europe and available measures for mitigation. In Ungulate Management in Europe: Problems and Practices (eds R.J. PutMan, M. ApPollonio \& R. ANDERSEN), pp. 215259. Cambridge University Press, Cambridge.

LAUndRÉ, J.W., HeRnÁndez, L. \& Altendorf, K.B. (2001) Wolves, elk, and bison: reestablishing the 'landscape of fear' in Yellowstone National Park, U.S.A. Canadian Journal of Zoology 79, 1401-1409.

LAUNDRÉ, J.W., HERNÁNDEZ, L. \& RIPPLE, W.J. (2010) The landscape of fear: ecological implications of being afraid. Open Ecology Journal 3, 1-7.

LAYTON, K.S. (2014) Chechens: Culture and Society. Palgrave MacMillan, New York.

Le Saout, S., Chollet, S., Chamaillé-Jammes, S., Blanc, L., Padié, S., Verchere, T., Gaston, A.J., Gillingham, M.P., Gimenez, O., PARker, K.L., Picot, Verheyden \& Martin, J.-L. (2014) Understanding the paradox of deer persisting at high abundance in heavily browsed habitats. Wildlife Biology 20, 122-135.

LENARZ, M.S. (2009) A review of the ecology of Parelaphostrongylus tenuis in relation to deer and moose in North America. In Summaries of wildlife research findings (eds M.W. DONCARLOS, R.O. KimmeL, J.S. LANWRENCE \& M.S. LeNARZ), pp. 70-75. Minnesota Department of Natural Reources, St. Paul, USA.

LeOPOLD, A., SOWLS, L.K. \& SPENCER, D.L. (1947) A survey of over-populated deer ranges in the United States. The Journal of Wildlife Management 11, 162-177.

LESCUREUX, N. (2018) Beyond wild and domestic: human complex relationships with dogs, wolves, and wolf-dog hybrids. In Hybrid Communities: Biosocial approaches to domestication and other trans-species relationships (eds C. StÉPANOFF \& J.-D. VIGNE), pp. 83-98. Routledge, London.

LesCuREuX, N. \& LinNELL, D.J.C. (2013) The effect of rapid social changes during post-communist transition on perceptions of the human-wolf relationships in Macedonia and Kyrgyzstan. Pastoralism: Research, Policy and Practice 3, 4. 
LesCUREUX, N. \& LinNelL, J.D. (2010) Knowledge and perceptions of Macedonian hunters and herders: the influence of species specific ecology of bears, wolves, and lynx. Human ecology 38, 389-399.

LETNIC, M. \& RIPPLE, W.J. (2017) Large-scale responses of herbivore prey to canid predators and primary productivity. Global Ecology and Biogeography 26, 860-866.

LinNeLL, J.D. \& AlLEAU, J. (2016) Predators that kill humans: myth, reality, context and the politics of wolf attacks on people. In Problematic Wildlife (ed F. ANGELICI M.), pp. 357-371. Springer, Cham.

LINNELL, J.D., SWENSON, J.E. \& ANDERSON, R. (2001) Predators and people: conservation of large carnivores is possible at high human densities if management policy is favourable. Animal Conservation 4, 345-349.

Linnell, J.D., TrouWborst, A. \& Fleurke, F. (2017) When is it acceptable to kill a strictly protected carnivore? Exploring the legal constraints on wildlife management within Europe's Bern convention. Nature Conservation 21, 129-157.

Linnell, J.D.C., Andersen, R., Andersone, Z., Balciauskas, L., Blanco, J.C., BoitAni, L., Brainerd, S.M., BREITENMOSER, U., KOJOLA, I. \& LIBERG, O. (2002) The fear of wolves: a review of wolf attacks on people. NINA Oppdragsmelding 731: 65pp. 731.

LÖE, J. \& RÖSKAFT, E. (2004) Large carnivores and human safety: a review. AMBIO: a journal of the human environment 33, 283-288.

MACMILLAN, D.C. \& LEITCH, K. (2008) Conservation with a gun: understanding landowner attitudes to deer hunting in the Scottish Highlands. Human ecology 36, 473-484.

MANN, C.C. (2005) 1491 : new revelations of the Americas before Columbus, 1st edition. Knopf, New York.

MARTIN, J.-L. \& BALTZINGER, C. (2002) Interaction among deer browsing, hunting, and tree regeneration. Canadian Journal of Forest Research 32, 1254-1264.

Martin, J.-L., Stockton, S.A., Allombert, S. \& Gaston, A.J. (2010) Top-down and bottom-up consequences of unchecked ungulate browsing on plant and animal diversity in temperate forests: lessons from a deer introduction. Biological Invasions 12, 353-371.

MARtin, T.G., ARCESE, P. \& SCheERder, N. (2011) Browsing down our natural heritage: deer impacts on vegetation structure and songbird populations across an island archipelago. Biological Conservation 144, 459-469.

MCCABE, R.E. \& MCCABE, T.R. (1984) Of slings and arrows: An historical retrospection. In WhiteTailed Deer: Ecology and Management (ed L.K. HALLS), pp. 19-72. Stakepole Books, Harrisburg, PA. 
McCone, K. (1987) Hund, Wolf und Krieger bei den Indogermanen. In Studien zum indogermanischen Wortschatz (ed W. MEID), pp. 101-154. Institut für Sprachwiss., Innsbrück.

MCDOWELL, R.W. (2008) Water quality of a stream recently fenced-off from deer. New Zealand Journal of Agricultural Research 51, 291-298.

MCSHEA, W.J. \& RAPPOLE, J.H. (2000) Managing the abundance and diversity of breeding bird populations through manipulation of deer populations. Conservation Biology 14, 11611170.

MECH, L.D. (2001) Managing Minnesota's recovered wolves. Wildlife Society Bulletin 29, 70-77.

MECH, L.D. \& BoITANI, L. (2003) Wolf social ecology. In Wolves: Behavior, Ecology, and Conservation (eds L.D. MECH \& L. BoITANI), pp. 1-35. University of Chicago Press, Chicago \& London.

MeCH, L.D., Fritts, S.H., Radde, G.L. \& PaUL, W.J. (1988) Wolf distribution and road density in Minnesota. Wildlife Society Bulletin (1973-2006) 16, 85-87.

MeCh, L.D., Harper, E.K., Meier, T.J. \& PAUL, W.J. (2000) Assessing factors that may predispose Minnesota farms to wolf depredations on cattle. Wildlife Society Bulletin 28, 623-629.

Melis, C., Jędrzejewska, B., Apollonio, M., Bartoń, K.A., JęDrzejeWski, W., Linnell, J.D.C., Kojola, I., Kusak, J., Adamic, M., Ciuti, S., Delehan, I., Dykyy, I., Krapinec, K., Mattioli, L., SAgaydak, A., et AL. (2009) Predation has a greater impact in less productive environments: variation in roe deer, Capreolus capreolus, population density across Europe. Global Ecology and Biogeography 18, 724-734.

Mercier, H. \& Sperber, D. (2011) Why do humans reason? Arguments for an argumentative theory. Behavioral and brain sciences 34, 57-74.

MerigGI, A. \& LovarI, S. (1996) A review of wolf predation in southern Europe: does the wolf prefer wild prey to livestock? Journal of applied ecology 33, 1561-1571.

MESSIER, F. (1994) Ungulate population models with predation: a case study with the North American moose. Ecology 75, 478-488.

Meuret, M. \& ProvenzA, F.D. (eds) (2014) The art \& science of shepherding: tapping the wisdom of French herders. Acres, Austin.

Middleton, A.D., Kauffman, M.J., McWhirter, D.E., Jimenez, M.D., Cook, R.C., CoOK, J.G., Albeke, S.E., SAWYER, H. \& WHITE, P.J. (2013) Linking anti-predator behaviour to prey demography reveals limited risk effects of an actively hunting large carnivore. Ecology Letters 16, 1023-1030. 
Miller, R., Kaneene, J.B., Fitzgerald, S.D. \& Schmitt, S.M. (2003) Evaluation of the influence of supplemental feeding of white-tailed deer (Odocoileus virginianus) on the prevalence of bovine tuberculosis in the Michigan wild deer population. Journal of Wildlife Diseases 39, 84-95.

Milner, J.M., Bonenfant, C., Mysterud, A., Gaillard, J.-M., Csanyı, S. \& Stenseth, N.Chr. (2006) Temporal and spatial development of red deer harvesting in Europe: biological and cultural factors. Journal of Applied Ecology 43, 721-734.

Mladenoff, D.J., Sickley, T.A., HAight, R.G. \& WydeVen, A.P. (1995) A regional landscape analysis and prediction of favorable gray wolf habitat in the northern Great Lakes region. Conservation Biology 9, 279-294.

MLAdenOfF, D.J., SickLeY, T.A. \& WydeVen, A.P. (1999) Predicting gray wolf landscape recolonization: logistic regression models vs. new field data. Ecological Applications 9, 37-44.

Morehouse, A.T. \& BoyCE, M.S. (2011) From venison to beef: seasonal changes in wolf diet composition in a livestock grazing landscape. Frontiers in Ecology and the Environment 9, 440-445.

MoReLL, V. (2008) Wolves at the Door of a More Dangerous World. Science 319, 890-892.

MoReLL, V. (2013) Predators in the 'Hood. Science 341, 1332-1335.

MORICEAU, J.-M. (2011) L'homme contre le loup: une guerre de deux mille ans. Fayard, Paris.

MoRIzOT, B. (2016) Les Diplomates. Wildproject, Marseille.

Moss, M.L. (1999) Heart and Blood: Living with Deer in America. American Anthropologist 101, 684-685.

Mounet, C. (2007) Les territoires de l'imprévisible. Conflits, controverses et 'vivre ensemble' autour de la gestion de la faune sauvage. Le cas du loup et du sanglier dans les Alpes françaises. Université Joseph-Fourier-Grenoble I.

Muhly, T.B. \& MusIANI, M. (2009) Livestock depredation by wolves and the ranching economy in the Northwestern US. Ecological Economics 68, 2439-2450.

Musiani, M., Mamo, C., Boitani, L., Callaghan, C., Gates, C.C., Mattel, L., Visalberghi, E., Breck, S. \& VOLPI, G. (2003) Wolf depredation trends and the use of fladry barriers to protect livestock in western North America. Conservation Biology 17, 1538-1547.

Myers, J.A., Vellend, M., Gardescu, S. \& MARKS, P.L. (2004) Seed dispersal by white-tailed deer: implications for long-distance dispersal, invasion, and migration of plants in eastern North America. Oecologia 139, 35-44. 
Mysterud, A., Easterday, W.R., Stigum, V.M., Aas, A.B., Meisingset, E.L. \& ViLugrein, H. (2016) Contrasting emergence of Lyme disease across ecosystems. Nature Communications 7 , 11882.

Mysterud, A. \& RolAndSEN, C.M. (2018) A reindeer cull to prevent chronic wasting disease in Europe. Nature ecology \& evolution 2, 1343.

Naughton-Treves, L., Grossberg, R. \& Treves, A. (2003) Paying for tolerance: rural citizens' attitudes toward wolf depredation and compensation. Conservation biology 17, 15001511.

NeLSON, R.K. (1998) Heart and blood: Living with deer in America. Knopf, New York.

NICKERSON, R.S. (1998) Confirmation bias: A ubiquitous phenomenon in many guises. Review of general psychology 2, 175.

NIE, M.A. (2002) Wolf recovery and management as value-based political conflict. Ethics, place \& environment 5, 65-71.

NILSSON DAHLSTROM, Å. (2009) 'Shoot, dig, and shut up!' Differing perceptions of wolves in urban and rural Sweden. Ethnologie française 39, 101-108.

Ostfeld, R.S., CAnham, C.D., Oggenfuss, K., Winchcombe, R.J. \& Keesing, F. (2006) Climate, deer, rodents, and acorns as determinants of variation in Lyme-disease risk. PLoS biology 4 , e145.

Ostfeld, R.S., LeVI, T., Keesing, F., Oggenfuss, K. \& CAnHAM, C.D. (2018) Tick-borne disease risk in a forest food web. Ecology 99, 1562-1573.

Papageorgiou, N., Vlachos, C., Sfougaris, A. \& TSachaldis, E. (1994) Status and diet of wolves in Greece. Acta Theriologica 39, 411-416.

PAULY, D. (1995) Anecdotes and the shifting baseline syndrome of fisheries. Trends in ecology \& evolution 10, 430.

PePIN, K.M., KAY, S.L. \& DAVIS, A.J. (2017) Comment on:'Blood does not buy goodwill: allowing culling increases poaching of a large carnivore'. Proc. R. Soc. B 284, 20161459.

Peterson, R.O., Vucetich, J.A., Bump, J.M. \& SMITH, D.W. (2014) Trophic cascades in a multicausal world: Isle Royale and Yellowstone. Annual Review of Ecology, Evolution, and Systematics 45, 325-345.

PhILLIP, S., DANDY, N., GILL, R. \& MACMILLAN, D.C. (2009) Is legislation a barrier to the sustainable management of game species? A case study of wild deer in Britain. Journal of Environmental Planning and Management 52, 993-1012. 
Poulle, M.-L., Carles, L. \& Lequette, B. (1997) Significance of ungulates in the diet of recently settled wolves in the Mercantour mountains (southeastern France). Revue d'Ecologie (Terre Vie) 52, 357-368.

Pulliainen, E., Hissa, R., Lehtelä, S., Rautiainen, L. \& Plester, L. (1999) Suurpetomme: karhu, susi, ahma, ilves. Articmedia.

Putman, R., Apollonio, M. \& ANdersen, R. (2011) Ungulate management in Europe: problems and practices. Cambridge University Press, Cambridge.

PUTMAN, R.J. \& StAINES, B.W. (2004) Supplementary winter feeding of wild red deer Cervus elaphus in Europe and North America: justifications, feeding practice and effectiveness. Mammal Review 34, 285-306.

RaghaVAN, M. (2008) Fatal dog attacks in Canada, 1990-2007. The Canadian veterinary journal = La revue veterinaire canadienne $49,577-581$.

Rand, P.W., Lubelczyk, C., Lavigne, G.R., Elias, S., Holman, M.S., Lacombe, E.H. \& SMith, R.P. (2003) Deer density and the abundance of Ixodes scapularis (Acari: Ixodidae). Journal of medical entomology 40, 179-184.

RASKER, R. \& HACKMAN, A. (1996) Economic development and the conservation of large carnivores. Conservation Biology 10, 991-1002.

RAYNOR, J.L. (2017) Essays on Measuring the Economic Impacts of Keystone Species. The University of Wisconsin-Madison.

Redpath, S.M., Young, J., Evely, A., Adams, W.M., Sutherland, W.J., Whitehouse, A., Amar, A., LAMBERT, R.A., LINNELL, J.D. \& WATT, A. (2013) Understanding and managing conservation conflicts. Trends in ecology \& evolution 28, 100-109.

Reimoser, F. \& PUtMAN, R. (2011) Impacts of wild ungulates on vegetation: costs and benefits. In Ungulate management in Europe: problems and practices. (eds R. PUTMAN, M. APOLLONIO \& R. ANDERSEN), pp. 144-191. Cambridge University Press, Cambridge.

RigG, R., Finďo, S., WeChSelberger, M., Gorman, M.L., Sillero-Zubiri, C. \& Macdonald, D.W. (2011) Mitigating carnivore-livestock conflict in Europe: lessons from Slovakia. Oryx 45, 272280.

RIPPLE, W.J. \& BESCHTA, R.L. (2012) Large predators limit herbivore densities in northern forest ecosystems. European Journal of Wildlife Research 58, 733-742.

Ripple, W.J., Estes, J.A., Beschta, R.L., Wilmers, C.C., Ritchie, E.G., HebbleWhite, M., Berger, J., Elmhagen, B., Letnic, M., Nelson, M.P., Schmitz, O.J., SMith, D.W., Wallach, A.D. \& WiRsing, A.J. (2014) Status and Ecological Effects of the World's Largest Carnivores. Science 343, $151-+$. 
RIPPLE, W.J., LARSEN, E.J., ReNkIN, R.A. \& SMITH, D.W. (2001) Trophic cascades among wolves, elk and aspen on Yellowstone National Park's northern range. Biological conservation 102, 227-234.

Rizzoli, A., Hauffe, H., Carpi, G., Vourc, H.G., Neteler, M. \& Rosa, R. (2011) Lyme borreliosis in Europe. Euro Surveill 16, 19906.

ROONEY, T.P. (2001) Deer impacts on forest ecosystems: a North American perspective. Forestry 74, 201-208.

ROONEY, T.P. \& WALLER, D.M. (2003) Direct and indirect effects of white-tailed deer in forest ecosystems. Forest Ecology and Management 181, 165-176.

Rooney, T.P., WIEgmann, S.M., Rogers, D.A. \& WalleR, D.M. (2004) Biotic Impoverishment and Homogenization in Unfragmented Forest Understory Communities. Conservation Biology 18, 787-798.

SACKS, J.J., LOCKWOOD, R., HORNREICHT, J. \& SATTIN, R.W. (1996) Fatal dog attacks, 1989-1994. Pediatrics 97, 891-895.

SCHAAP, W. \& DEYOE, D.R. (1986) Seedling protectors for preventing deer browse. In pp. 1-12. Research Bulletin, Forest Research Laboratory, Oregon State University, Corvallis, Or.

Schmitt, S.M., Fitzgerald, S.D., Cooley, T.M., Bruning-Fann, C.S., Sullivan, L., Berry, D., Carlson, T., MiNNIS, R.B., PAYEUR, J.B. \& SIKARSKIE, J. (1997) Bovine tuberculosis in free-ranging whitetailed deer from Michigan. Journal of Wildlife Diseases 33, 749-758.

SCHMITZ, O.J., BECKERMAN, A.P. \& O'BRIEN, K.M. (1997) Behaviorally mediated trophic cascades: effects of predation risk on food web interactions. Ecology 78, 1388-1399.

SHARP, R. \& Wollscheid, K.-U. (2009) An overview of recreational hunting in North America, Europe and Australia. In Recreational hunting, conservation and rural livelihoods (eds B. Dickson, J. Hutton \& W. AdAms M.), pp. 25-38. Wiley and Sons, Oxford.

ShARPE, V.A., Norton, B.G. \& Donnelley, S. (2001) Wolves and human communities: biology, politics, and ethics. Island Press, Washington D.C.

Shelton, A.L., HenNing, J.A., SChULtZ, P. \& Clay, K. (2014) Effects of abundant white-tailed deer on vegetation, animals, mycorrhizal fungi, and soils. Forest Ecology and Management 320, 39-49.

Sidorovich, V.E., TIKHOMIROVA, L.L. \& JedRZEJEWSKA, B. (2003) Wolf Canis lupus numbers, diet and damage to livestock in relation to hunting and ungulate abundance in northeastern Belarus during 1990-2000. Wildlife Biology 9, 103-111. 
SKOGEN, K. (2003) Adapting adaptive management to a cultural understanding of land use conflicts. Society \&Natural Resources 16, 435-450.

Skogen, K. \& Krange, O. (2003) A Wolf at the Gate: The Anti-Carnivore Alliance and the Symbolic Construction of Community. Sociologia ruralis 43, 309-325.

Smietana, W. \& Klimek, A. (1993) Diet of wolves in the Bieszczady Mountains, Poland. Acta Theriologica 38, 245-251.

SMith, D.W., Peterson, R.O. \& Houston, D.B. (2003) Yellowstone after wolves. BioScience 53, 330-340.

Stockton, S.A., Allombert, S., Gaston, A.J. \& Martin, J.-L. (2005) A natural experiment on the effects of high deer densities on the native flora of coastal temperate rain forests. Biological Conservation 126, 118-128.

Storm, D.J., Nielsen, C.K., Schauber, E.M. \& Woolf, A. (2007) Deer-human conflict and hunter access in an exurban landscape. Human-Wildlife Conflicts 1, 53-59.

Storm, D.J., Samuel, M.D., Rolley, R.E., Shelton, P., Keuler, N.S., Richards, B.J. \& Van Deelen, T.R. (2013) Deer density and disease prevalence influence transmission of chronic wasting disease in white-tailed deer. Ecosphere 4, 1-14.

STRICKLAND, D. (2009) What Originally Prevented, and what Later Permitted, the Great Northern Expansion of White-tailed Deer? The friends of Algonquin Park, Whitney, On.

Suominen, O., Niemelä, J., Martikainen, P., Niemelä, P. \& Kojola, I. (2003) Impact of reindeer grazing on ground-dwelling Carabidae and Curculionidae assemblages in Lapland. Ecography 26, 503-513.

TALlamy, D.W. \& RAuPP, M.J. (1991) Phytochemical induction by herbivores. John Wiley and Sons, Oxford.

Tanner, E., White, A., Acevedo, P., Balseiro, A., Marcos, J. \& Gortázar, C. (2019) Wolves contribute to disease control in a multi-host system. Scientific reports 9, 7940.

TelfoRd, I., SAM R. (2017) Deer Reduction Is a Cornerstone of Integrated Deer Tick Management. Journal of Integrated Pest Management 8, 25-25.

Telford III, S.R., Mather, T.N., Moore, S.I., Wilson, M.L. \& Spielman, A. (1988) Incompetence of deer as reservoirs of the Lyme disease spirochete. The American journal of tropical medicine and hygiene 39, 105-109.

TERBORGH, J. \& EsteS, J.A. (2010) Trophic cascades: predators, prey, and the changing dynamics of nature. Island Press, Washington D.C. 
Terborgh, J., Holt, R.D., Estes, J.A., Terborgh, J. \& Estes, J. (2010) Trophic cascades: what they are, how they work, and why they matter. Trophic cascades: predators, prey, and the changing dynamics of nature 1, 18.

THIEL, R.P. (1985) Relationship between road densities and wolf habitat suitability in Wisconsin. American Midland Naturalist 113, 404-407.

Thinley, P., Rajaratnam, R., Lassoie, J.P., Morreale, S.J., Curtis, P.D., Vernes, K., Leki, L., Phuntsho, S., DORJI, T. \& DORJI, P. (2018) The ecological benefit of tigers (Panthera tigris) to farmers in reducing crop and livestock losses in the eastern Himalayas: Implications for conservation of large apex predators. Biological Conservation 219, 119-125.

TILGHMAN, N.G. (1989) Impacts of white-tailed deer on forest regeneration in northwestern Pennsylvania. The Journal of Wildlife Management 53, 524-532.

TREVES, A. \& BonACIC, C. (2016) Humanity's dual response to dogs and wolves. Trends in ecology \& evolution 31, 489-491.

TREVES, A. \& KARANTH, K.U. (2003) Human-carnivore conflict and perspectives on carnivore management worldwide. Conservation Biology 17, 1491-1499.

Treves, A., Krofel, M. \& McManus, J. (2016) Predator control should not be a shot in the dark. Frontiers in Ecology and the Environment 14, 380-388.

Treves, A., NAUGhtON-TREVES, L., Harper, E.K., Mladenoff, D.J., Rose, R.A., Sickley, T.A. \& WYDEVEN, A.P. (2004) Predicting human-carnivore conflict: A spatial model derived from 25 years of data on wolf predation on livestock. Conservation Biology 18, 114-125.

Treves, A., NAughton-Treves, L. \& Shelley, V. (2013) Longitudinal analysis of attitudes toward wolves. Conservation Biology 27, 315-323.

URBIGKIT, C. \& URBIGKIT, J. (2010) A review: the use of livestock protection dogs in association with large carnivores in the Rocky Mountains. Sheep \& Goat Research Journal 25.

U.S. DePARTMENT OF THE INTERIOR (2017) 2016 National Survey of Fishing, Hunting, and WildlifeAssociated Recreation. U.S. Department of the Interior, U.S. Fish and Wildlife Service, and U.S. Department of Commerce, U.S. Census Bureau, Washington, DC.

VerCAUTEREN, K. (2003) The deer boom : discussions on population growth and range expansion of the white-tailed deer. In Bowhunting records of north america whittail deer. (eds G. HISEY \& K. HISEY), pp. 15-20. Pope and Young Club, Chatfield, MN.

Vicente, J., Höfle, U., Garrido, J.M., Fernández-De-Mera, I.G., Juste, R., Barral, M. \& Gortazar, C. (2006) Wild boar and red deer display high prevalences of tuberculosis-like lesions in Spain. Veterinary research 37, 107-119. 
Vila, B., TORRE, F., Guibal, F. \& MARTIN, J.-L. (2003a) Growth change of young Picea sitchensis in response to deer browsing. Forest Ecology and Management 180, 413-424.

Vila, B., Torre, F., Martin, J.-L. \& GUiBAL, F. (2003b) Response of young Tsuga heterophylla to deer browsing: developing tools to assess deer impact on forest dynamics. Trees 17, 547-553.

WALLER, D.M. (2014) Effects of deer on forest herb layers. The herbaceous layer in forests of Eastern North America, 369-399.

WALleR, D.M. \& AlVERSON, W.S. (1997) The white-tailed deer: a keystone herbivore. WildI Soc Bull 25:217-226. Wildlife Society Bulletin 25, 217-226.

Wardle, D.A., Barker, G.M., Yeates, G.W., Bonner, K.I. \& Ghani, A. (2001) Introduced browsing mammals in New Zealand natural forests: aboveground and belowground consequences. Ecological monographs 71, 587-614.

WARREN, R.J. (1997) The challenge of deer overabundance in the 21st century. Wildlife Society Bulletin 25, 213-214.

WebB, G.K. (2016) Public Management Decisions Related to the Decline of California Deer Populations: A Comparative Management Approach. Environment and Ecology Research 4, 63-73.

WEST, B.C. \& PARKHURST, J.A. (2002) Interactions between deer damage, deer density, and stakeholder attitudes in Virginia. Wildlife Society Bulletin 30, 139-147.

Widman, M., SteEn, M. \& Elofsson, K. (2017) Consequential costs of sheep depredation by large carnivores in Sweden. In pp. 1-31. Swedish University of Agricultural Sciences, Department of Economics, Uppsala.

WIEGMANN, S.M. \& WALLER, D.M. (2006) Biotic homogenization in forest understories: identity and traits of historical "winners" and "losers". Biological Conservation 129, 109-123.

WILLIAMS, C.K., ERICSSON, G. \& HeberLEIN, T.A. (2002) A Quantitative Summary of Attitudes toward Wolves and Their Reintroduction (1972-2000). Wildlife Society Bulletin 30, 575-584.

WILSON, J.B. \& AGNEW, A.D. (1992) Positive-feedback switches in plant communities. Advances in ecological research 23, 263-336.

Wilson, M.L., Adler, G.H. \& Spielman, A. (1985) Correlation between abundance of deer and that of the deer tick, Ixodes dammini (Acari: Ixodidae). Annals of the Entomological Society of America 78, 172-176.

Wilson, M.L., LeVInE, J. \& SpIeLman, A. (1984) Effect of deer reduction on abundance of the deer tick (Ixodes dammini). The Yale journal of biology and medicine 57, 697. 
Wilson, M.L., Litwin, T.S., Gavin, T.A., Capkanis, M.C., Maclean, D.C. \& Spielman, A. (1990) Hostdependent differences in feeding and reproduction of Ixodes dammini (Acari: Ixodidae). Journal of medical entomology 27, 945-954.

Wilson, M.L., Telford III, S.R., PIESMAN, J. \& SPIELMAN, A. (1988) Reduced abundance of immature Ixodes dammini (Acari: Ixodidae) following elimination of deer. Journal of Medical Entomology 25, 224-228.

WindeLS, S.K. \& FLASPOHLER, D.J. (2011) The ecology of Canada Yew (Taxus canadensis Marsh.): a review. Botany $89,1-17$.

WINNIE JR, J.A. (2012) Predation risk, elk, and aspen: tests of a behaviorally mediated trophic cascade in the Greater Yellowstone Ecosystem. Ecology 93, 2600-2614. 


\section{Legends of Figures}

3 Fig. 1. Map of North America showing the distribution of cervid populations in November 2016

4 infected with Chronic Wasting Disease (CWD) and the states and provinces where CWD occurs

5 within captive populations. Source: http://cwd-info.org/map-chronic-wasting-disease-in-north-

6 america/

8 Fig. 2. Non-linear responses to shifts in deer density impede our ability to detect trophic cascades.

9 The lower curve depicts the initial effects of increases in deer on a plant population. These

10 remain subtle and difficult to demonstrate $(\mathrm{A})$ until the plant population is depleted to a threshold

11 density at which point it can rapidly disappear (B). Conversely, the upper curve shows how

12 substantial reductions in deer density (perhaps for an extended time) may bring little apparent

13 effect on the plant population (A) until the plant population escapes herbivory enough to recover

14 rapidly (B). Under such ecological hysteresis, cumulative impacts of deer herbivory act to delay

15 and obscure the effects of deer on plant populations except over particular (and different) short

16 intervals (B).

18 Fig. 3. Schematic illustration of the asymmetry in appreciation (confirmation bias) of relative costs and benefits of recoveries of deer and wolves in a context of deer 'overabundance'. The two

20 dominant polarized views (A and D) refer to wolf recovery in a context of large deer populations.

21 Minority views are reflected in boxes B and $\mathrm{C}$. The relative size of the boxes within each figure

22 relative the relative importance of costs and benefits within a given appreciation category. The

23 size and shape of arrows reflect the relative importance of given to specific costs or benefits

24 when developing an argumentation. Large full arrows identify confirmation biases, dashed

25 narrow arrows identify biases against provided evidence. 
27 Fig. 1.

28

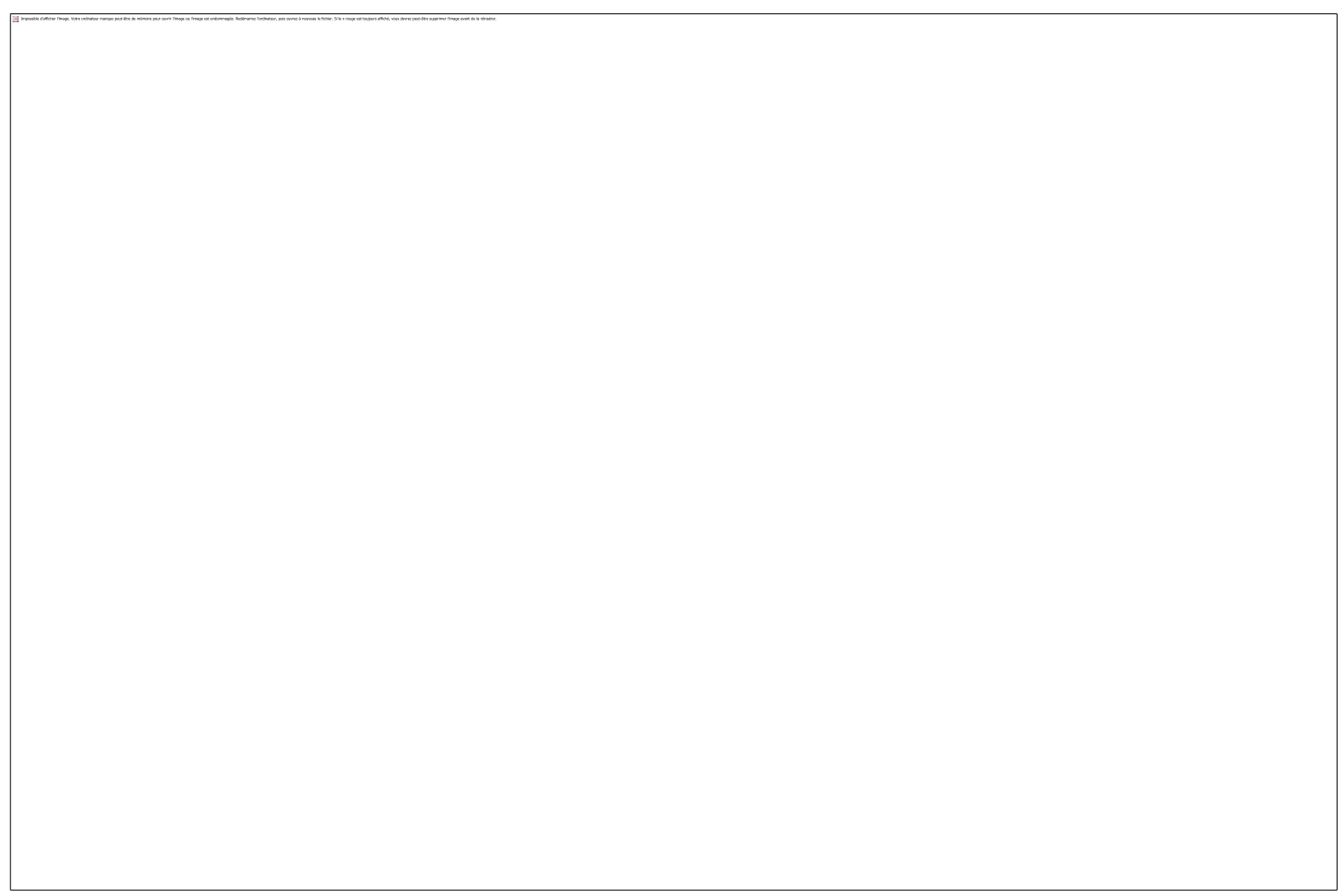


29 Fig. 2.

30

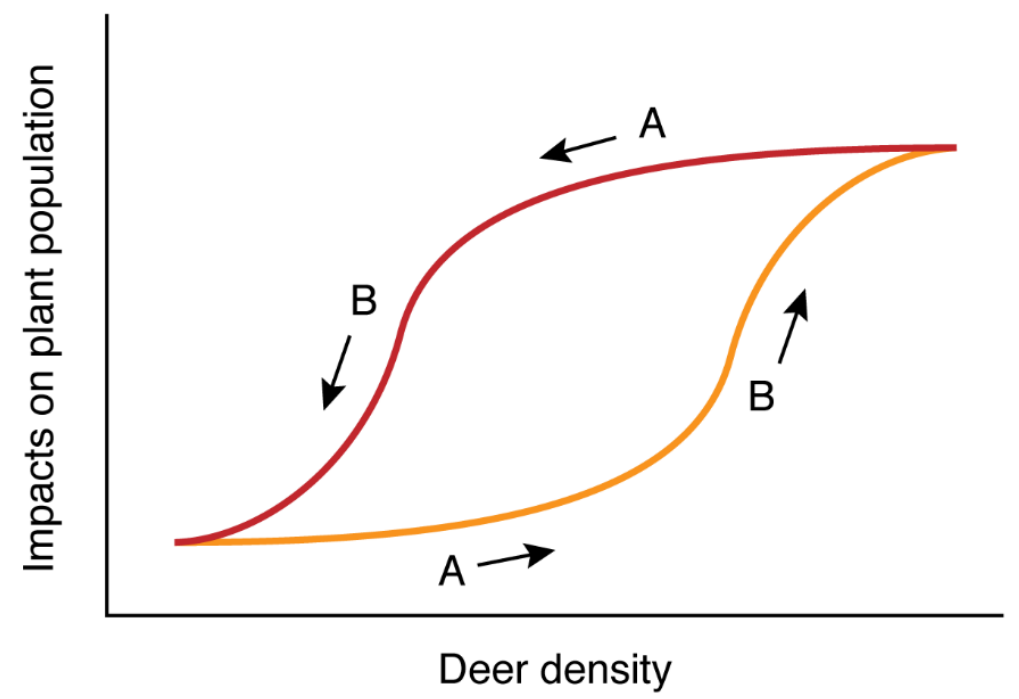

31

32 
34 Fig. 3.

35

36
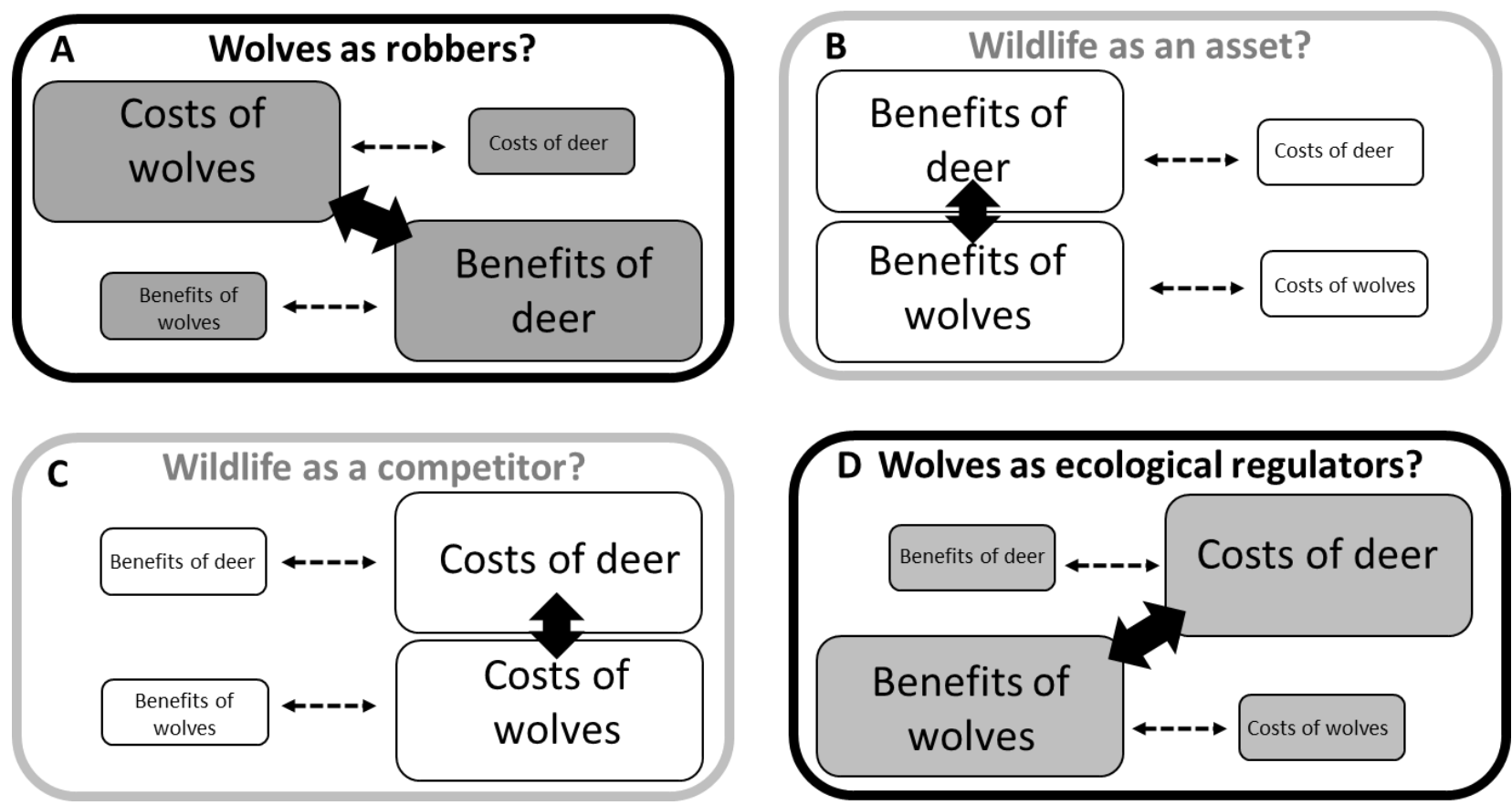

38

39

40

41

42 
43 Table 1. Synthesis of costs and benefits as perceived by society associated with dense deer

44 populations with examples of references.

\begin{tabular}{lll}
\hline Effects of deer on: & Benefits & Costs \\
\hline Wildlife & $\begin{array}{ll}\text { Recreational hunting (Sharp \& } \\
\text { Wollscheid, 2009) }\end{array}$ & $\begin{array}{l}\text { Reduce forage for other species (Beck } \\
\text { \& Peek, 2005) }\end{array}$ \\
& Wildlife viewing opportunities (Duffus \& & $\begin{array}{l}\text { Threats from parasites and disease } \\
\text { (Schmitt } \text { et al., 1997; Rizzoli } \text { et al., } \\
\end{array}$ \\
& Dearden, 1990) & $2011)$ \\
\hline
\end{tabular}

\begin{tabular}{ll}
\hline Ecological conditions & $\begin{array}{l}\text { Deer reduce yew cover, favouring other } \\
\text { understorey plant species (Windels \& } \\
\text { Flaspohler, 2011) }\end{array}$
\end{tabular}

Reduce understorey plant cover and diversity (Côté et al., 2004)

Reduce animal diversity (birds) (McShea \& Rappole, 2000; Chollet \& Martin, 2013)

Biotic homogenization (Rooney et al., 2004)

Facilitate invasions of exotic worms, plants and diseases (e.g. Dávalos et al., 2015)

$\begin{array}{ll}\text { Ecosystem processes } & \text { Facilitation of native plant dispersal } \\ & \text { (Myers } \text { et al., 2004; Albert } \text { et al., 2015) }\end{array}$

Facilitation of invasive plant seed dispersal (Myers et al., 2004) and invasive plant establishment (Knight et al., 2009)

Accelerate nutrient cycling and nutrient losses (Harrison \& Bardgett, 2004), increasing stream pollution (McDowell, 2008)

Soil compaction, reduced infiltration, more erosion eg. (Shelton et al., 2014)

Declines in soil carbon (Maillard, 2019)

Eventual declines in forest tree carbon sequestration and storage (to be studied) Putman et al., 2011)

Limit regeneration in many tree species (e.g. Schaap \& DeYoe, 1986)

Sparse \& simplified under- and midstorey conditions (e.g. Stockton et al., 2005) 
Outdoor pursuits

Tick-borne diseases (Lyme, babesiosis, erhlicheosis, etc.) (e.g. Rizzoli et al., 2011)

Wildlife health

Reservoir for bovine tuberculosis (Schmitt et al., 1997)

Parasites limit abundance of elk, moose, etc. (Lenarz, 2009)

Chronic Wasting Disease (Storm et al., 2013)

45 